\title{
LA UGT DE MADRID EN LOS AÑOS TREINTA: UN SINDICALISMO DE GESTION
}

Santos Juliá

\section{Introduccion: sindicalismo e industria}

La periodización del proceso técnico-industrial establecida por Touraine era demasiado sugestiva como para no edificar sobre ella una correlativa periodización del sindicalismo, tanto más cuanto que las dos formas organizativas clásicas de los sindicatos parecen adecuarse y corresponder con bastante exactitud a las fases de Touraine. Fue Serge Mallet el primero en señalar la correspondencia entre el sindicalismo de oficio y la fase A del capitalismo industrial y entre el sindicalismo de industria y la fase B, con la Carta de Amiens de 1906 como gozne simbólico de la transición de uno a otro. Mallet vincula la existencia del sindicalismo de «metier» a lo que llama fase familiar o de grupo del capitalismo, caracterizada por la existencia de múltiples empresas que aseguran la fabricación íntegra de un producto. El trabajo está dividido en su forma más simple y las distintas ramas

Nota PREVIA. Este artículo se basa fundamentalmente en los boletines de las sociedades obreras miembros de la UGT. Debido al largo título que suelen tener, he preferido citar con abreviaturas excepto en la voz que designa el oficio. Así, el Boletín de la Federación Local de Obreros en Madera se citará BFLO Madera. Esta norma será válida excepto para Boletín de la Unión General de Trabajadores de España, que se cita Boletín UGT. La abreviatura AHNS seguida de un número indica que el documento en cuestión se encuentra en la sección de Madrid del Archivo Histórico Nacional de Salamanca, en la carpeta correspondiente al número citado. 
industriales no son más que los antiguos oficios, integrados por obreros cuya única diferencia radical con el antiguo artesano es que se encuentra desposeído de los medios de producción. En el taller capitalista, como antes en el artesanal, el trabajador impone todavía su propio ritmo de producción y el de su cuadrilla. El taller se compone en realidad de múltiples células relativamente autónomas que producen para un mercado local y que reciben de la localidad las materias primas. Todo el proceso de trabajo descansa sobre la posesión de una cualificación profesional que es la única posesión real que le queda al obrero. Las sociedades de oficios velarán precisamente por la defensa de esa cualificación reivindicando la reapropiación de los medios de producción de que se ha despojado al antiguo artesano. Las sociedades se organizan por ramas corporativas y no por ramas industriales; la tasa de sindicación es muy alta; las asambleas se repiten a menudo y las acciones implican a una amplia mayoría del oficio, lo que permite tachar de traidores y negar el pan y la sal a quienes se atreven a no seguir las órdenes de la sociedad. Este tipo de organización es básicamente local, muy descentralizado, con una fuerte solidaridad interna que las constituye en comunidades cerradas ${ }^{1}$.

La aparición y expansión de la gran empresa y la consiguiente transformación técnica del trabajo, con la sustitución del obrero cualificado por el obrero especialista, aniquila la eficacia del sindicalismo de oficio. La masiva demanda de trabajadores no cualificados, la posibilidad para las empresas de sustituir su mano de obra o de formarla en el mismo puesto de trabajo, la descomposición técnica del trabajo con la sustitución de los viejos nombres de los oficios por categorizaciones abstractas son algunas de las razones que explican la necesidad de un nuevo tipo de sindicalismo que sustituya a las viejas sociedades. Son los sindicatos de industria, con una fuerte implantación en el hábitat obrero más que en el oficio, y con una tendencia a la centralización nacional por medio de las federaciones de industria. Uniones obreras locales y federaciones nacionales de industria son las dos características esenciales de la nueva forma organizativa que adopta el sindicalismo. Lo demás puede entenderse como resultado lógico de esa estructura: crecimiento de una burocracia sindical; establecimiento de canales regulares de negociación con las empresas; coordinación entre la lucha sindical y la política; nueva relación que se establece entre una minoría sindicada y la mayoría de los obreros que permanece fuera de las fronteras sindicales ${ }^{2}$.

Válida en sus líneas fundamentales, esta teorización es insuficiente para explicar las diferencias a veces fundamentales que pueden existir en el interior de la propia división. En el caso de España, por ejemplo, tanto la UGT como la CNT

1 Para la periodización de Touraine, véase “Organisation professionelle de l'entreprise", en G. Frredman y P. Navilie, Traité de Sociologie du Travail (París, 1961), I, páginas 387-427. Lo de Mallet es de "syndicalisme et société industrielle", en La nouvelle classe ouvrière (París, 1969), págs. 51-67. Para otras clasificaciones del sindicalismo desde el punto de vista genético, estructural y funcional, Michel Crozier, "Sociologie du syndicalisme", también en Frisdmann y Navilie, II, 170-193.

2 Maliet, loc. cit. Según Friedmann y Treanton, el sindicalismo de oficio es "particularista y maltusiano", mientras que el de industria sería más "sensible a la solidaridad de todos los trabajadores", en su artículo "Sociologie du syndicalisme, de l'autogestion ouvrière et des conflicts du travail", en G. Gurvitch, Traité du sociologie (París, 1962), I, pág. 480. 
serían sindicatos de industria si se les considera formalmente. Ambos se organizan según el modelo clásico de este sindicalismo: sociedades locales que se federan localmente y federaciones locales que se federan nacionalmente, en el caso de la UGT; sindicatos únicos de industria en el caso de la CNT. Con esto no se sabe nada, sin embargo, de los procesos de toma de decisión, del tipo predominante de dirigente sindical, de los encontrados mundos de la ideología y los valores, de los diversos vínculos que se establecen entre dirigentes y afiliados y entre éstos y el resto de los trabajadores de la industria, ni, en fin, de las prácticas muchas veces antagónicas que caracteriza a cada sindicato. Definirlos como sindicatos de industria no es suficiente para dar cuenta de sus profundas diferencias.

Lo insuficiente de la clasificación radica, por otra parte, en la misma posibilidad de concebir teóricamente fases de transición de una a otra forma de sindicalismo, que pueden durar largos períodos de tiempo y en las que los elementos realmente dominantes pueden ser distintos e incluso contradictorios de los que resultan de la definición formal del sindicato. Pueden coexistir, más concretamente, en el mismo sindicato un reglamento que lo define como de industria con un tipo de dirección predominantemente gremial o con una ideología de fuertes resonancias artesanas. En una federación local de industria puede darse el caso de una sociedad de oficio organizada según el más puro modelo gremial. El mismo hecho de la transición no lineal de la fase A a la B del capitalismo y los consiguientes desfases entre organización técnica del trabajo, relaciones sociales de producción, concentración de capital, dispersión del hábitat, etc., podría exigir una más compleja clasificación de los modelos sindicales, aunque sólo se tuviera en cuenta su correspondencia con la industria ${ }^{3}$.

Por otra parte, esa clasificación es insuficiente porque sólo atiende a la hipotética correspondencia estructural entre industria y sindicato sin tener en cuenta la específica y diferenciada historia de éste. De hecho, es un error vincular la aparición del sindicalismo de oficio al primer período del capitalismo industrial y a la clase obrera directamente afectada en su trabajo por la expansión de las nuevas formas de producción industrial. Las nuevas sociedades obreras son el resultado final de un largo proceso de cambio en la organización industrial, de la que la muy afamada revolución industrial es sólo uno de los momentos. Tal proceso se aceleró en los siglos XVII y xVIII, esto es, antes de las profundas mutaciones producidas por la revolución industrial, debido al rápido crecimiento del comercio mundial, a la sustancial mejora en las comunicaciones, a la división y especialización del trabajo y sólo en contadas industrias a la introducción de maquinaria en grandes fábricas. En ese largo proceso, la revolución industrial significa la liquidación final del sistema llamado de manufactura, algunos de cuyos elementos entraron ya en crisis durante el siglo Xvi, y su sustitución por un nuevo sistema caracterizado, para lo que aquí interese, por el control absoluto del proceso de trabajo por la clase capitalista, gracias a la sustitución del trabajo manual por el mecánico, y a la simultánea generalización de la posesión privada del medio de

${ }^{3}$ Touraine advierte que su división no debe confundirse con un "esquema histórico" y argumenta la posibilidad de que el elemento "económico" de la fase B subsista en la fase A: op. cit., págs. 392-393. 
producción por el propio capitalista que hasta entonces lo había dejado en manos del productor directo.

La aparición de las primeras sociedades obreras de oficio obedece simplemente a la resistencia de los trabajadores a este proceso de control del trabajo por parte de la nueva clase capitalista, y a las bases de las que parten esas sociedades serán las viejas formas organizativas de los trabajadores para la defensa de sus gremios.

Lo importante para nuestro caso es que muchos elementos de este primer sindicalismo, que acompaña al avance de la fábrica, perdurarán en los sindicatos del siglo xx hasta que la generalización del trabajo fabril asegure, por medio de la concentración masiva de trabajadores y la implantación de una rígida disciplina laboral, el control total del proceso de trabajo. Hasta que ese fenómeno no se produce, el sindicalismo se define sobre todo por el intento de resistir a la paulatina y creciente implantación de ese control. Las prácticas sindicales dominantes en el período se explican precisamente como resistencia a ese control y los sectores obreros que más duramente resistirán, y que mejor organizados estarán, serán precisamente aquellos que todavía gocen de alguna independencia y sientan que la paulatina pérdida de su control sobre el proceso de trabajo se resuelve en pérdida de su condición relativamente privilegiada en el mercado de trabajo. Naturalmente, las formas de actuación que adopta esa defensa no pueden ser ya, con la amenaza de la fábrica, las mismas que antes, pero el sentido es idéntico; la quema de máquinas es la negociación colectiva por la violencia; la huelga es generalmente la defensa de la capacidad de compra ante un mercado cuyo control han perdido; las exigencias de cualificación para ingresar en el oficio es lo único que queda para controlar el mercado de trabajo ante la avalancha de los no cualificados o los especialistas. Y para organizar tales prácticas, se revitalizan las mutuas, las sociedades amicales, las uniones de oficios con las que esta específica clase obrera de la revolución industrial opondrá una resistencia ordenada y firme a esta pérdida de su viejo control sobre el oficio ${ }^{4}$.

Los obreros que, a pesar de todo, conservan cierta cualificación y alguna independencia son los verdaderos creadores de las sociedades de resistencia y toda la práctica societaria posterior, hasta la expansión del sindicalismo de masas, será en algún sentido su heredera. Ciertamente, el sindicalismo que corresponde a la expansión industrial se edificará sobre otras bases: la fábrica moderna, la producción mecanizada y a gran escala, la división y fragmentación del trabajo, su «organización científica», la especialización del hábitat. Esas bases provocarán una práctica sindical muy diferente, servida por una organización distinta. Los obreros no de-

${ }^{4}$ Es imposible dar cuenta, aun somera, de la ingente literatura sobre la formación de los sinđicatos. Pueden verse, como mera guía de lo que aquí se dice y para el caso inglés: Henry Pelling, $A$ History of British Trade Unionism (Harmondsworth, 1977), páginas 17-32, y A. E. Musson, British Trade Unionism. 1800-1875 (Londres, 1979), págs. 1221. En el clásico libro de los WeBB, The History of Trade Unionism (Clifton, 1973, reimp.), se insiste en los elementos de continuidad del sindicalismo respecto a las sociedades de obreros cualificados. Para el diferente desarrollo del "new unionism" a partir de 1870 y el cambio en la organización y los procedimientos de actuación, Keith Burgess, The Origins of British Industrial relations (Londres 1975). He intentado una elaboración más detallada de lo que aquí se argumenta en "Marx y la clase obrera de la revolución industrial", en Teoria, 8 (octubre-diciembre 1981). 
fienden ya sus viejas trincheras - han perdido toda esperanza de controlar un proceso de trabajo que les viene impuesto por la propia máquina que, además, ha arruinado ya la cualificación del oficio- sino que se movilizan sobre todo para la defensa y mejora de las condiciones pactadas en los contratos de trabajo. La dimensión del sindicato, la organización por industria, el tipo de obrero en ellos dominante, los objetivos que se trazan son coherentes con una organización interna mucho más centralizada y burocratizada y muy relacionada, por otra parte, con los partidos políticos, especialmente con la socialdemocracia de finales de siglo, cuya política determina en múltiples ocasiones ${ }^{5}$. Ahora bien, la transición hasta ese nuevo tipo de sindicalismo, más racionalizado y con gran poder en algunos centros de decisiones políticas, ocupará todavía largas dácadas en las que la práctica sindical estará inspirada en algunos casos, dominada en otros, por las herencias que llegan de un reciente pasado.

\section{Cuatro sindicalismos en el Madrid de la República}

Como es bien sabido, entre los procesos sociales que puso en marcha o aceleró la proclamación de la II República en España no fue el menor la movilización obrera. Cuatro organizaciones sindicales intentarán controlar en Madrid esa movilización y canalizar sus demandas. Y lo van a intentar de muy distinta manera, poniendo en juego diferentes mecanismos, organizando la acción según diferentes pautas, rodeando a sus movimientos de muy distintas coreografías y buscándoles diferentes y aun opuestas salidas. Todo ello configura cuatro tipos diversos de sindicalismo que no quedarían suficientemente definidos por la habitual distinción en sindicatos de oficios o de industria ni algunas otras habitualmente utilizadas por los sociólogos de las relaciones laborales. En Madrid, cuya estructura industrial es todavía muy débil, que carece de grandes fábricas en aquellos sectores productivos en los que históricamente apareció el sindicalismo de industria, que tiene abundancia de pequeños y medianos talleres de artes tradicionales, y en fin, donde únicamente se produce una concentración masiva de trabajadores no cualificados en el sector de la construcción, los sindicatos están situados en algún momento de la transición del modelo de oficio al de industria. Si los más poderosos se definen como sindicatos de industria o se esfuerzan por serlo, la herencia de las viejas sociedades de oficio es todavía notable no sólo en la ideología dominante o en el tipo de dirección, sino incluso en la propia estructura organizativa. Así, será imposible definir a la UGT como sindicato de oficio, pero todavía no podrá decirse de ella, porque así recen sus estatutos o porque así se organice formalmente, que sea un moderno sindicato de industria. Lo mismo cabe afirmar de la CNT, que se organiza según el modelo de sindicatos únicos de industria, pero cuyos contenidos ideológicos o cuyos procesos de toma de decisión, por no hablar ya de su situación

s Para las complejas relaciones entre los sindicatos alemanes y el partido socialdemócrata antes de la primera guerra es muy útil Carl E. Schorsḱ, German Social Democracy, 1905-1917 (Nueva York, 1972), especialmente el capitulo "The extension of trade union influence", págs. 88-105. 
respecto a lo político, poco tienen que ver con el modelo total de este sindicalismo ${ }^{6}$.

Por tanto, y como la historia sindical se define sobre todo por las diferentes etapas de las acciones emprendidas por cada organización y por el sentido que a esas acciones se atribuye, aquí se propone precisamente el punto de vista de la práctica sindical dominante para clasificar a los distintos sindicatos que se mueven en el Madrid de los años treinta. Como se verá por el estudio de cada caso, las formas organizativas, las ideologías, los valores morales, las actuaciones concretas de los dirigentes, la relación entre sindicalismo y política, están estrechamente relacionadas con el tipc de práctica dominante en cada organización y con lo que de ella se espera.

Y por empezar con el más poderoso y añejo de los sindicatos de Madrid, la UGT, su práctica al llegar la República es heredera directa de la que caracterizó a las sociedades de oficio, con el añadido sustancial de haber conquistado ya cierto favor del Estado, en su intento de canalizar corporativamente las demandas obreras y el conjunto de relaciones laborales. Compuestas y dirigidas por obreros cualifcados en las artes tradicionales - algunas de ellas en clara decadencia- que defienden una posición de relativo privilegio en el mercado de trabajo, por medio de la conciliación de intereses y la negociación con pequeños y medianos patronos bajo la tutela del Estado. Se trata de sociedades bien asentadas, en algunos casos numerosas, respetadas y respetables, con unas prácticas ampliamente legitimadas ante la opinión pública, ante los patronos y ante el Estado, y que por el hecho del crecimiento cuantitativo de sus efectivos más que por las transformaciones cualitativas de las industrias en que trabajan han tenido que centralizar sus decisiones dando así origen a una burocracia sindical estable, que gestiona con eficacia los intereses de las sociedades obreras federadas. Si se considera la práctica global de la organización, este sindicalismo podría denominarse de gestión, pues lo que le caracteriza son sobre todo las gestiones desarrolladas por los dirigentes estables del sindicato para la defensa de los intereses societarios.

Frente a este sindicalismo, y precisamente en el sector en que el crecimiento cuantitativo de una industria está provocando ya importantes cambios en la organización del trabajo con la aparición de grandes sociedades anónimas que arrebatan a los pequeños y medianos patronos su antigua hegemonía en el sector, crece otro sindicato cuya práctica se define por la continua llamada a la movilización de masas obreras no cualificadas. Podría sospecharse que se trata de un moderno sindicalismo de industria, pero carece por completo de burocracia, sus afiliados no van a fábricas, su ideología está dominada por la vieja esperanza de los

6 "Es forzoso reconocer que en la organización obrera preside un espíritu de autonomía que (...) aconseja que sea el sistema federativo y no el sindicato el que se adopte para dar nueva estructura a la Unión General", escribe LaRgo Caballero en Presente y futuro de la Unión General de Trabajadores de España (Madrid, 1925), págs. 230-231. $Y$ ya en la República, El Obrero Gráfico, xi.1931, se enfrenta "a los iracundos sembradores del desamor a la organización federativa que tratan de volverla al primitado estado de sociedades aisladas de oficio". Por lo demás, es conocida la fuerza que el mito de la "grand soir" - característico del sindicalísmo de oficio, según Mallet, página 58- tiene en el sindicalismo de industria anarquista. 
oficios tradicionales en los efectos taumatúrgicos de una huelga general. He preferido, pues, llamar a este sindicalismo, por su práctica dominante, de movilización de masas ${ }^{7}$.

Entre ambos hay un proyecto sindical que se presenta en un primer momento como reconstrucción de la CNT, pero que más adelante dará lugar a la creación de un sindicato de siglas francesas - la CGTU-, y cuya práctica se circunscribe en estos primeros tiempos de República a la agitación en el seno de otras organizaciones sindicales y entre sectores de población poco estructurados o que acceden por vez primera a la práctica sindical y atraviesan un período de fuerte radicalización política. Así, por una parte, agitarán en el seno de la CNT y, a través de unos llamados grupos sindicales de oposición, de la UGT. Intentarán a la vez organizar comités de parados por barrios y grupos sindicales de dependientes, empleados y enseñantes. Por su práctica dominante, este sindicalismo podría denominarse perfectamente de agitación ${ }^{8}$.

Finalmente, y con muy escasa incidencia en las luchas sociales del período, hay también un sindicalismo que se pasa la mayor parte de la República en un vano intento de definirse confesional o profesionalmente. Tienen algunos efectivos entre empleados y categorías profesionales cualificadas e intentarán a partir de los sucesos de octubre de 1934 acaparar el mercado sindical madrileño ante la obligada retirada de sus adversarios. Esta salida al exterior es, sin embargo, atípica de este sindicalismo que se contenta con organizar a los trabajadores católicos y a pedir insistentemente a sus patronos que no contraten a obreros de otra ideología. Se contentan, por decirlo brevemente, con vivir en el gueto. Su mentalidad es la del sitiado y su práctica se dirige casi exclusivamente a que los patronos católicos den trabajo a los obreros católicos. Es un sindicalismo de gueto ${ }^{9}$.

Si hubiera que definir con una fórmula breve lo que ocurre en Madrid durante la República en el ámbito sindical, habría que decir que el sindicalismo de gestión

7 He tratado de este modelo sindical en "Un sindicalismo de movilización de masas en el Madrid de la Segunda República", Estudios sobre Historia de España (homenaje a Tuñón de Lara) (Madrid, 1981), 2, págs. 151-160.

- Una exposición de la política sindical comunista del período puede encontrarse en el folleto Los sindicatos en la revolución española (Barcelona, s/f., pero 1933).

" Para entender lo que pretende el sindicalismo católico, puede verse el comentario de "Carpesom" (Carlos Pérez Sommer) a un documento del cardenal primado sobre creación de bolsas de trabajo. Decía el primado: "Son muchos, por desgracia, los católicos irreflexivos que no reparan en el doble mal que hacen cuando favorecen y acreditan con sus compras, encargos, consultas, lecturas, etc., a personas y empresas que poco o nada atienden a las leyes de la moralidad o de la justicia, o que tal vez ni siquiera respetan nuestra santa religión, antes la combaten y ultrajan; y no solicitan, como fuera lógico, equitativo y caritativo, los productos, los servicios y los trabajos de aquellos otros que añaden a sus méritos $y$ cualidades, en orden a lo material $y$ económico, una honradez acrisolada, una fe viva y laboriosa $y$, tal vez, un amor ferviente $\mathrm{y}$ abnegado por el reinado social de Jesús." $\mathrm{Y}$ "Carpesom" pedirá a las "empresas periodísticas de carácter católico que construyen sus casas o editan sus periódicos con obreros socialistas o neutros", y a las "comunidades y sacerdotes que hacen lo propio" y, en fin, a "los católicos pudientes", que se "pongan la mano en el pecho" y "lean detenidamente ese documento". El documento del primado -que pretende crear una "Bolsa Española de Trabajo" para patronos y obreros católicos manuales o intelectuales, puede verse íntegra en $E l E c o$ del Pueblo, 31.xii.1930. Los comentarios de "Carpesom" no se hacen esperar: El Eco del Pueblo, 15.1.1931. 
entra en crisis ante el avance del sindicalismo de movilización de masas y el fracaso del sindicalismo de agitación y del de gueto. La CNT, cuyas primeras salidas a las calles madrileñas tres meses después de proclamarse la República se saldan en un completo fracaso, está sin duda alguna a la cabeza de los movimientos huelguísticos de octubre de 1933 y volverá a estarlo durante la primavera de 1936. Es un sindicato que se siente crecido en su victoria. La UGT, sin embargo, que entra en la República con gran fuerza y dueña prácticamente del mercado sindical, pierde posiciones a medida que pasan los meses y que todo el tinglado de relaciones laborales pacientemente instalado desde la dictadura primorriverista se muestra incapaz de resolver los graves problemas sociales que acompañan a la caída de actividad económica. A partir de principios de 1934, la UGT querrá recuperar el terreno perdido durante los primeros años elaborando un nuevo discurso político y cambiando su ejecutiva nacional. Las páginas que siguen se dedican exclusivamente a indagar en la naturaleza del modelo sindical que dominó las luchas obreras madrileñas hasta el otoño de 1933.

\section{Un sindicato con amplia legitimidad social}

Lo primero que llama la atención al estudiar la UGT madrileña de comienzos de la República es la legitimidad de que goza en amplios y muy diversos sectores sociales. La Federación Patronal Madrileña, en un editorial que trataba del «peligro comunista», había señalado que «todo patrono consciente de sus responsabilidades ha de inclinarse al lado de los elementos socialistas» en el pleito que a principios de 1931 dividía a los sindicatos de Madrid. De hecho, no sólo los patronos se inclinan por ellos. En los comienzos del nuevo régimen no hay en Madrid quien no se deshaga en alabanzas y plácemes a la "clase obrera organizada», ya sea por «su conducta ejemplar evidenciada constantemente», como afirma la Cámara de Industria; ya por la «disciplina y entusiasmo enorme» hacia sus «ideales sociales», como se escribe en El Sol; ya porque la misma proclamación de la República y la «forma» en que se ha producido son frutos de la «siembra del apóstol» Iglesias, como escribe Queipo de Llano; ya, en fin, por la «disciplina austera e inteligente» que ha posibilitado el «momento maravilloso» de que habla Cossío. El encanto de la UGT trascendía los muros de la Casa del Pueblo y legitimaba a aquella masa disciplinada que en ella recibía educación ante ese conjunto de patronos, industriales, periodistas, militares o intelectuales que veían en ella el principal soporte de la República ${ }^{10}$.

Tal acuerdo general era compartido, naturalmente, por la propia UGT, orgullosa de sus orígenes sin mancilla, de su historia de calladas renuncias y sacrifi-

10 "El peligro comunista", en El Eco Patronal, 1.i.1931. El "aplauso para la clase obrera colaboradora del Gobierno" fue adoptado por la Cámara de Industria de Madrid en sesión de 27.v.1931: "Libro de Actas de la Cámara Oficial de Industria, 1930-1934" fol. 53, y publicado en Industria, mayo 1931, que añade al aplauso la complacencia. La opinión de $E l$ Sol, en número de 2.v.1931. La visita de Queipo de Llano a la Casa del Pueblo y las frases que escribe en su álbum, también en El Sol, 29.iv.1931, y del mismo periódico, 10.vii.1931, la entrevista con Manuel Bartolomé Cossío. 
cios, de lentas e irreversibles conquistas, de sus apóstoles y sus ritos, de sus fiestas y celebraciones, y embargada y, a las veces, embriagada por aquella constante sensación de superioridad moral que le daba el hecho de ser y saberse la más prestigiosa organización de la clase obrera. Prestigio en el que encontraban su mayor timbre de gloria y al que no estaban de ningún modo dispuestos a renunciar, pues provenía de su indiscutible control sobre una clase obrera que recibía de ella educación societaria y dirección política. Limpieza de orígenes, fidelidad a lo que fue, sacrificio, prestigio, control, educación, disciplina, dirección; conceptos todos que, en su continua repetición en los documentos emanados de la UGT - sea cual fuere su grupo dirigente- compendian una manera de ser y de hacer, un específico modelo sindical ${ }^{11}$.

Alabanzas y autocomplacencia eran, en verdad, merecidas. Los procesos de legitimación sindical son largos y están erizados de obstáculos. Si la UGT está legitimada ante el Estado, ante la mayoría de los sectores patronales e industriales de Madrid y ante sí misma es porque los trabajadores madrileños se reconocen en ella y tienen en ella su sindicato. La UGT es, sin duda, el sindicato de los trabajadores de Madrid y, en consecuencia, es el organismo que introduce una específica racionalidad en las relaciones laborales de la capital. Importa investigar de qué racionalidad se trata, pues de su exacta comprensión dependerá la intelección del proceso de su quiebra y de los intentos _-esta vez carentes de legitimaciónpor introducir otro tipo de relación laboral. Tanto se ha insistido en la determinación de este proceso de cambio y ruptura por las nuevas actitudes presuntamente revolucionarias adoptadas por los órganos dirigentes, que será preciso intentar un camino distinto. $\mathrm{Y}$ para comenzar, lo más inmediato consiste en saber con la mayor exactitud qué era y qué hacía la UGT de Madrid a principios de la República. Una vez conocido esto, será posible luego entender la profunda crisis por la que atraviesa a medida que la República avanza.

\section{Sociedades $y$ afiliados}

Albañiles de las artes de la construcción: ésta es la categoría predominante en la UGT madrileña a principios de la República. No, desde luego, que toda la UGT sea un sindicato de albañiles, sino que ellos y los peones de las mismas

"La UGT tiene una historia caracterizada por la "claridad" -circular de 22.vi.1932, en Memoria y orden del día del XVII Congreso Ordinario, pág. 51- y sus avances se interpretan siempre como "sacrificio": Enrique DE SANTIAGo, La UGT en la revolución española (Madrid, 1932), págs. 43-44, para el sacrificio que exige la participación en los comités paritarios; y Nota de las dos Ejecutivas, en Boletín UGT, vii.1932, para el sacrificio de las "legítimas reivindicaciones" exigido por la defensa de la República. Para la "pureza de nuestros ideales", véase circular "La UGT a todas las federaciones y secciones", de 17.vi.1931, AHNS, 1883. Para la "conciencia plena de su valer" que embarga a sus "hombres", El Metalúrgico, v.1932. La "solidaridad ideal", la "firmeza de nuestra organización" y "nuestra disciplina interna" se resaltan como la mejor aportación que pueda hacerse a la "nación", en BFLO Madera, iii.1930. Para el resto de los conceptos, véase Exhortación", en Boletín UGT, vi.1933; además, la serie de notas - manifiestos recopiladas en Memoria y orden del día, ya citado, y también "El Partido Socialista y la Unión General de Trabajadores al proletariado", en Boletín UGT, v.1934. 
artes cuentan por más de la mitad de la Federación Local de la Edificación que, a su vez, representa un tercio de toda la UGT de Madrid y su provincia. Podrá aventurarse, pues, desde ahora una hipótesis: lo que ocurra en el sector de la construcción va a tener una importancia decisiva en toda la UGT madrileña, no sólo porque a ella pertenece un tercio aproximado de la organización sindical, sino porque otras industrias con alto nivel de sindicación viven de la construcción, de ella dependen y sólo en ella trabajan. Entre las principales, naturalmente, la pequeña metalurgia, cuyos obreros se encuadran en uno de los principales sindicatos ugetistas, El Baluarte, que cuenta con algo más de 7.000 afiliados. Más moderno que la mayor parte de las sociedades obreras de la construcción — se funda en 1919-, El Baluarte es una de las primeras organizaciones ugetistas que se titula sindicato, y cuenta ya con la experiencia de algunas huelgas importantes y sostenidas incluso contra la opinión y las advertencias de la Federación nacional ${ }^{12}$.

De la época del sindicato metalúrgico, y con un número de afiliados que ronda los 6.000, datan también de los varios sindicatos de Artes Blancas, entre los que sobresale con mucho el de obreros en pan candeal, con sus 2.566 afiliados. Más modernos, pero muy pujantes, son los diversos sindicatos ferroviarios y los de transporte urbano. El primero cuenta, según el censo electoral social, con 4.430 miembros, mientras que a los segundos estarían adscritos 16.346 trabajadores, la mitad de los cuales pertenecerían a la Sociedad de Obreros del Transporte Mecánico. Entre los muy recién llegados y los que todavía «se incorporan rápidamente» hay que destacar a los diversos sindicatos de Banca y oficinas y a los de profesiones liberales. Junto a los que parece masiva entrada de jóvenes de sociedades y sindicatos tradicionales, esta pujanza del sindicalismo de empleados -que elaboran un discurso político muy diferente al que había sido patrimonio de las viejas burocracias sindicales- será un factor decisivo en la dislocación de la UGT madrileña a partir del verano de $1933^{13}$.

«La Asociación obrera más antigua de Madrid», esa «aristocracia del arte tipográfico a quien principalmente se deben la Unión General y el Partido Socialista», cuyos sesenta y un años de existencia se han dedicado a «organizar, encauzar, administrar, dirigir, discutir y aún disputar; afrontar crisis de ambiente y crisis de hombres, desoír pesimismos, sacudir emperezamientos, autoeducarse sobre la

12 La sociedad de albañiles "El Trabajo" tiene en abril de 1931 algo más de diez mil afiliados, El Trabajo, xi.1931. Los afiliados de todos los oficios de la construcción serían 25.646, según el órgano de la federación local, La Edificación, 15.xi.1931. Los metalúrgicos serían 6.206 en abril y mil más en septiembre, El Baluarte, vii-viii.1931, aunque en las sesiones del XIV Congreso de la Federación Siderometalúrgica aparecen representados poco más de cinco mil y en la estadística del Boletín UGT, 15.x.1931 no hay más que 3.898. Véase para congreso, Federación Siderometalúrgica de España, Actas de las sesiones del XIV Congreso (Madrid, 1932), págs. 2 y 3. Las censuras de la Federación a "El Baluarte" por la huelga general metalúrgica de Madrid, en El Metalúrgico, i.1931.

${ }^{13}$ Los números proceden de la estadística general de afiliados que publica Boletín UGT, 15.x.1931, claramente sobreestimados en algunos casos y que se deberán confrontar con Boletín UGT, supl. n. 34 , 1931, y Boletín Ministerio Trabajo, supl. n. $\circ 29$, xii.1931, que dan relación nominal de sociedades. La rápida incorporación al sindicato de Banca, que merece un comentario muy propio en el sentido de que debian purificarse de sus posibles culpas pequeño-burguesas, en Bancario, i.1933. 
marcha, desbaratar ataques burgueses de diverso tipo, y todo ello en un plano de honestidad, desinterés y modestia», es sin duda el Arte de Imprimir, compendio de virtudes ugetistas, "cuna de un gigante» y todavía de peso numérico considerable, pues cuenta con algo más de 2.000 socios. Con la Asociación de Impresores, que tiene 1.320 , y con las centenas que componen el resto de las sociedades de Artes Gráficas dan un total para este grupo de poco más de 6.000 afiliados. Con la Agrupación General de Camareros, de finales del siglo xIx; la Asociación General de Dependientes de Comercio, del año 1902, y con una difícil historia de escisiones y sindicatos opuestos, y, en fin, las diversas y también añejas sociedades de obreros en madera -especialmente los carpinteros de taller y los ebanistas, a cuyas filas «la libertad ha traído... gran número de compañeros»componen las más importantes sociedades obreras de la UGT de Madrid. Hay, sin duda, muchas más, ya que precisamente la constitución de sociedades para cada oficio y la multiplicidad de éstos da lugar a una verdadera atomización asociativa. En los señalados hasta aquí reside, sin embargo, la verdadera fuerza de la UGT madrileña ${ }^{14}$.

En resumen, pues, la UGT representa con bastante exactitud a la clase obrera y a los trabajadores de Madrid, no ya porque sea o deje de ser su conciencia o su cobijo, sino por la más sencilla razón de que en ella se inscriben en proporción que refleja bastante bien la estructura industrial de la ciudad. Su contingente más numeroso, cuando comienzan los años treinta, pertenece a la construcción - y den. tro de ella a la albañilería- y enseguida a los demás oficios tradicionales: pequeña metalurgia, artes blancas, madera, artes gráficas. Aparte de estos grupos industriales, quienes cuentan en la UGT son los trabajadores de servicios, especialmente de los transportes, pero afirmándose cada vez más, los empleados y oficinistas, y con una fuerza nada desdeñable, los dependientes y camareros. Las federaciones de edificación, gráficas, metalurgia, dependencia, transporte urbano y transporte ferroviario constituyen, con holgura. más de la mitad de la UGT madrileña, en la que pueden contarse hasta 34 industrias. Habrá que tener en cuenta esta complejidad organizativa y las distintas situaciones por que atraviesan oficios e industrias para entender luego las diferentes respuestas que se dará dentro de la UGT a las nuevas coyunturas sindicales y políticas.

\section{La «organización obrera»}

Esta UGT de Madrid repite básicamente en su estructura el tipo de organización industrial todavía predominante, el de los oficios. Cada uno tiene su socie-

${ }^{14}$ La referencia a la aristocracia es de J. J. Morato, "En vísperas de unas bodas de oro", El Obrero Gráfico, xi.1931. La relación de funciones cumplidas en BOA Arte de Imprimir, xi.1932. El incremento de ebanistas, en BS Ebanistas, ii.1932, que da 540 afiliados para 1930 y 1.280 para 1932 . El crecimiento acelerado de los de madera, en BFLO Madera, xii.1931. En Federación, v.1932, que da cuenta del Congreso de la Federación, aparecen 2.427 camareros y 860 cocineros. Según BA Dependientes Espectáculos Públicos, esta sociedad tendría 1.025 asociados al finalizar el primer semestre de 1932, ix.1932. El Boletín UGT, 15.x.1931, da un total para Madrid y su provincia de 191.198 afiliados, de los que 68.562 pertenecerían a edificación, lo que parece una clara exageración. 
dad, que se federa con otras para constituir una industria o, más exactamente, la federación local de una industria. Si esta federación local no existiera, la sociedad se vincula directamente a la Unión. Las federaciones pueden tener un número muy elevado de sociedades de oficio. En la de edificación, por ejemplo, se albergan hasta 23 asociaciones que, por estatutos, gozan de autonomía en todo lo que se refiere a sus asuntos internos aunque deban supeditarse a los organismos centrales en lo que se relacione con la «actuación de conjunto». Es el comité de sección quien inicia todas las gestiones societarias relativas y admisión y despido de asociados en las fábricas o talleres, el que interviene cuando se anuncia un conflicto, quien toma sobre sí la responsabilidad de darle uno u otro cauce, aunque siempre informe a los organismos superiores ${ }^{15}$. La autonomía societaria será muy relevante, sobre todo, a la hora de elaborar y discutir los contratos de trabajo en el seno de los comités paritarios o, después, en los jurados mixtos. La sociedad vela por la exacta definición de las atribuciones y competencias de cada categoría del oficio o suprime algunas que podrían servir como «válvula de escape por la que el patrono suplanta a las categorías con salarios de miseria». Tales competencias sobre el oficio darán lugar a una amplísima casuística que la respectiva sociedad tratará de normativizar por medio de prolijas definiciones que, entre otras cosas, permiten conocer hoy con toda exactitud lo que se podía esperar de -o pedir acada trabajador. Los jurados mixtos tendrán aquí, como es obvio, un amplio campo de actuación y no pocos problemas, que desaparecerán por completo con el propio hundimiento de los jurados ${ }^{16}$.

Cada federación de industria tiene un comité ejecutivo que suele reunir mensualmente al pleno de delegados de las secciones o sociedades de oficio. Tiene algún interés señalar que por encima del comité ejecutivo de las diversas federaciones locales se salta ya a la ejecutiva de la federación nacional. Esto es, no existe una ejecutiva local de la UGT madrileña. En la UGT, quienes negocian los acuerdos, declaran los conflictos o libran las batallas son las sociedades o secciones $\mathrm{y}$, en el mejor de los casos, las federaciones de industria si el caso trasciende al

15 Estos principios organizativos se mantienen en el proyecto de reforma de estatutos que se habría de presentar al Congreso de 1936. En su artículo 2, b), se dice que cada sociedad "es autónoma en el seno del organismo nacional y éste en el de la Unión General, en todos aquellos asuntos de incumbencia interna de las mismas, cuando no afecten a los asuntos de carácter general", aunque este proyecto refuerza las competencias de la ejecutiva nacional y, especialmente, del secretariado general, Boletín UGT, v-vi.1936, págs. 215-219. Para la declaración de huelgas, el acuerdo con organismos superiores era fundamental con objeto de conseguir la solidaridad moral - realizar ges. tiones en los más altos niveles- y la material - prestar apoyo económico-. Para ambas solidaridades era preciso haber informado previamente y obtenido el acuerdo de los órganos superiores: véanse estatutos del Congreso de 1888 en apéndice a Manuel PÉrEz LEDEsMa, "La primera etapa de la Unión General de Trabajadores (1888-1917)", en A. Balcells (ed.), Teoría y práctica del movimiento obrero en España (Valencia, 1977). Del interesante estudio de Pérez Ledesma se desprende que poco han cambiado los "planteamientos sindicales" desde los origenes a los años treinta.

${ }^{16}$ Se habla de válvula de escape en BOSO Carpinteros de taller, x.1933, cuando consiguen suprimir la categoría de aprendiz adelantado. Las definiciones de las categorías desaparecen por completo en las bases presentadas en 1936, por ejemplo, las de construcción, que se presentan con la CNT, Construcción, 9.v.1936, "Bases aprobadas en la Asamblea magna". 
oficio; nunca la UGT local. No existe tal cosa todavía. Los problemas y conflictos lo son de tal oficio y como mucho de tal industria, pero orgánicamente no se contempla que puedan serlo del conjunto de la clase obrera de la localidad. Esta carencia de un específico órgano ejecutivo local estará en la raíz de tantas y tan reiteradas deficiencias organizativas reveladas por la UGT cuando se decide a emprender acciones totales y será suplida, en la medida de lo posible, por la Junta Administrativa de la Casa del Pueblo, que representa estatutariamente a todas las sociedades y organizaciones afiliadas a la Casa, sean de carácter sindical, político o cultural, y sean o no afiliadas a la UGT. Al aumentar, con el transcurso de la República, las tensiones específicamente sindicales, la Junta Administrativa se verá obligada a incrementar sus intervenciones, casi siempre para negar los rumores de que se prepara alguna huelga general o para invitar a los trabajadores a que acudan a sus puestos aunque la CNT la haya convocado. Precisamente, una de las incapacidades orgánicas de la UGT local es declarar una huelga general en cualquier lugar en que existan diversas federaciones de industria, ya que no hay un comité local con competencias para hacerlo. En Madrid, la primera huelga general, convocada para un domingo, lo fue por las Juventudes Socialistas, y la segunda lo será por los comités ejecutivos nacionales de la UGT y el PSOE. Pues, en el caso de Madrid, aparte de la Junta Administrativa de la Casa del Pueblo, es obvia la importancia que para todas las federaciones de la UGT tiene el hecho de que sea Madrid el lugar de residencia del comité ejecutivo nacional, cuyos miembros pertenecen casi invariablemente a alguna federación de industria o a algún sindicato de la UGT de Madrid ${ }^{17}$.

Ese conjunto de sociedades y federaciones compone lo que los propios ugetistas llaman «la organización obrera» para distinguirla del Partido Socialista. Pero en el hecho de llamar a la UGT organización obrera o también «clase obrera organizada» hay algo más. El obrero comienza a ser algo —o deja de ser nadacuando se organiza, hasta el punto de que no habrá obrero consciente que no esté organizado. Tal insistencia en la organización revela, ante todo, la original racionalidad que la UGT introduce en las relaciones laborales madrileñas: a la atomización y dispersión de la actividad económica, repartida en cientos de pequeñas o medianas unidades productivas en las que un patrono - todavía llamado amo o dueño muchas veces- podía imponer en principio las condiciones de trabajo a un reducido número de obreros, la UGT opone la organización del oficio y, a

17 Algunos llamamientos de la Junta Administrativa pueden verse en Casa del Pueblo de Madrid, Memoria de la Junta Administrativa, octubre 1934 a junio 1936 (Madrid, 1936). Las confusiones a que podía dar lugar esta complejidad orgánica siempre resaltan en las convocatorias de huelgas generales. Así, en la primera que se convoca durante la República, la Federación Local de Obreros en Madera escribe directamente a la ejecutiva de la UGT comunicándole su acuerdo de ir a la huelga para impedir la "concentración fascista" de El Escorial. Responde el secretario general, Largo Caballero, considerando "improcedente" la convocatoria y manifestando su "opinión en contra": ambas cartas en AHNS, 2174. Esto ocurría el 20 de abril de 1934. En la tarde del día siguiente, las Juventudes Socialistas reparten unas octavillas en las que "invitan" a la huelga general, que tendrá lugar efectivamente el día 22, El Socialista, 22.iv.1934. La intervención de las ejecutivas nacionales en asuntos madrileños es continua y comienza enseguida, nota de 11.v.1931, Memoria y orden del día, pág. 41, y se acentuará, como veremos, en 1934 . 
través de las federaciones de oficios, intentará hacer presente, de forma corporativa, la organización de la clase. Así, los obreros no serán ya los dispersos elementos de la producción, sino la fuerza organizada del trabajo. Por ello, la UGT se compone sobre todo de «sociedades», que no es exactamente lo mismo que «sindicatos», palabra que designará a las nuevas organizaciones obreras de Madrid sólo a partir de 1918/20 y no siempre o no a todas. La Unión General es, efectivamente, lo que dice ser: una unión general, y serán palabras que denoten esta idea de unión las que sirvan para designar a las nacientes organizaciones de los oficios: sociedad obrera, asociación de obreros, sociedad general de obreros, agrupación o unión de empleados ${ }^{18}$.

De ahí que se exhorte con tanta frecuencia al «amor y fomento de la organización», a «amar a la sociedad», pues en ella encuentran los afiliados las relaciones fraternales, las ligaduras íntimas, el cobijo, la seguridad de formar un «todo indestructible», «una piña, un haz». De ahí también que en las tradiciones ugetistas se revista de tanta importancia la celebración del aniversario de la sociedad, día en que además del «renunciamiento a las bajas pasiones» y de unificar criterios, se llega a sentir en «las fibras del alma una alegría tan grande» que convertirá al afiliado en un «ser dichoso», junto a su familia, al son de viejas canciones e himnos entrañables, con las queridas enseñas desplegadas y emocionados por el recital de algunos versos ingenuos que narran las peripecias de la organización o las dificultades de una familia obrera. De ahí, en fin, quẹ muchas de las sociedades se esfuercen por publicar cada mes o cada trimestre un órgano de expresión propio, que convoquen a los afiliados para alguna velada musical o alguna comida de fraternidad y que inviten a las asambleas que periódicamente celebran para elegir o ratificar a sus representantes. Se trata, en definitiva, de crear lazos culturales entre elementos socialmente dispersos en sus centros de trabajo y en sus lugares de habitación ${ }^{19}$.

18 "Ayer no eran nada", dicen de sí los dependientes de casinos, mientras que ahora son ya "como los demás obreros organizados", BS Dependientes de Casinos, vii.1934. No faltan avisos "A los patronos" para que no se fíen de la vieja idiosincrasia de los obreros, porque "va perdiendo su anterior forma... para dar paso a una conciencia de clase", BA Fotograbadọres, i y x.1933. Por lo demás, es un axioma que la "resistencia patronal se vence siempre que así se lo propongan la organización y la entereza de los hombres", BOA Impresores, ii.1933.

19 Para el amor y fomento de la organización, véase Manuel JaIMEz, "Nuestra idea y nuestra táctica", en El Trabajo, viii.1931. Lo de la piña, el haz y todo lo demás es de "Una consigna: unión", BOA Arte Imprimir, xi.1932, y del mismo, xi.1931, "Recuerdo. ¡Fiesta de aniversario!" es lo de las pasiones, una referencia a las cuales podrá verse también en el artículo citado de Jaimez. Para la unificación de criterios, "Nuestro aniversario", BAO Litógrafos, i.1933. La dicha de pertenecer a una "organización modelo", en "Nuestro aniversario", BOA Estereotipadores, i.1933. La "simpática presencia de muchas compañeras que dieron esplendor y alegría al acto", en "Nuestro XXXII aniversario", BOAGO Cerradores $y$ Repartidores de Prensa, ii.1933. Un ejemplo de versos: "Viva la unión del obrero / Viva nuestra Sociedad / Viva la fraternidad / de todos los compañeros" que pueden verse en BOA Litógrafos, i.1934, aunque también se lelan en otras veladas como la que tiene lugar en la "inauguración de la bandera" según cuenta BA Dependientes Espectáculos Públicos, ix.1932. 


\section{Los organizadores y su gestión}

El énfasis en la organización remite de forma inmediata -además de a un mundo de valores impregnado de cierta unción religiosa de que se hablará luegoa los propios organizadores y a la relevancia de su acción y su iniciativa. La UGT es un sindicato de organizadores profesionales, esto es, de personas cuya tarea - «difícil y penosa a la vez, ingrata y escabrosa en demasía»- es la de organizar. Constituyen, por decirlo con palabras de uno de sus más respetados dirigentes, ese "pequeño grupo de compañeros escogidos que forman a modo de un brillante estado mayor» de aquella «masa obrera organizada» de la que «emergen». Se expresa así o con otras fórmulas equivalentes la distancia objetiva que media entre los miembros de la sociedad de oficio y sus dirigentes que se ven a sí mismos en contraposición polar nosotros/vosotros con aquéllos. Las reivindicaciones de los afiliados serán recogidas por sus dirigentes «con la atención que todos vuestros deseos y aspiraciones, siempre justos, nos merecen...» o se dirá también que «a nadie concedemos ni un ápice más de preocupación por vuestros destinos» cuando surgen algunos que pretenden hacerse portavoces de ellos. Tal contraposición, aparte de señalar una distancia, afirma una diferencia radical de funciones: "nosotros» es quien debe atender «vuestros» deseos o preocuparse por «vuestro» destino y, lo que es tan importante, ejecutar esos deseos, llevar a la práctica esas aspiraciones, darles «el cauce de seriedad... que en toda lucha sindical supieron siempre imprimir los organismos sindicales que, cual el nuestro, se inspiran en los redentores principios de la UGT». Y la mejor prueba de esa diferenciación de funciones, expresada en términos de atención y preocupación por los deseos de los demás, será la periódica «confección» de los contratos de trabajo, a los que se atribuye siempre la lenta y segura mejora de las condiciones de la vida obrera ${ }^{20}$.

$\mathrm{La}$ insistencia en la organización de la clase obrera se resuelve en afirmación de la exclusiva capacidad de iniciativa de los organizadores de la clase obrera. En su expresión más inmediata se dirá que «un solo compañero» es el que debe llevar «la voz»; en su más elaborada versión, aquel grupo de militantes al que se denomina «pequeño estado mayor» es el que compone «los organismos responsables»: ninguna iniciativa que provenga de otros, ninguna acción «que no esté organizada por los organismos responsables de la organización» será nunca secundada por el militante ugetista, que no atenderá «sino las indicaciones que provengan de los organismos centrales». La responsabilidad de la acción radica en el centro de la organización. Así, la Junta Administrativa de la Casa del Pueblo de Madrid, cada vez que tenga que desmentir los rumores de huelga general o ir a contracorriente de alguna acción alocada, recordará como argumento supremo y

${ }^{20}$ Los calificativos de la tarea de los organizadores que "exige, en respuesta, respeto y gratitud" en J. V., "Gratitud, cuando menos", BOA Estereotipadores, v.1933. Lo del "estado mayor" puede verse en "Lo que el momento actual exige de los trabajadores organizados", Boletín UGT, x.1933, pero la idea de que los organizadores son "los obreros más inteligentes", que "forman como una aristocracia, como una selección entre la propia clase trabajadora", es antigua y puede verse así expresada por Luis Araquistain, El ocaso de un régimen (Madrid, 1930), pág. 107. Las demás citas son de una nota de "El Baluarte", en El Sol, 10.vii.1931. 
último que tales «movimientos huelguísticos» no tienen el «aval» de la «organización». $Y$ tal recordatorio es indiferente a épocas y grupos dirigentes: la Junta de febrero de 1936 invocará el mismo principio cuando intente encauzar las manifestaciones de entusiasmo levantadas por el triunfo electoral de la izquierda: «Trabajadores: solamente a quien incumbe iniciar y organizar toda manifestación política es a los elementos directivos y responsables de las organizaciones obreras ${ }^{21}$.

Es más, algo hay de sucio y reprobable, un estigma, una especie de pecado de origen, en toda iniciativa, especialmente huelguística, que no parta de la propia organización. Las huelgas que se producen al margen de la UGT tienen siempre unos orígenes «sospechosos» y unos «turbios» propósitos. Sus objetivos, al no estar claramente «determinados», no pueden ser «limpios» ni «resplandecientes»; son, pues, huelgas «oscuras» que perjudican al «prestigio y la seriedad» de la organización obrera. Sus autores no sólo «hacen el juego» a los políticos reaccionarios, o arriesgan el «ser utilizados por nuestros propios enemigos», sino que son verdaderos agentes provocadores, auténticos y directos enviados de los políticos logreros», «elementos perturbadores», «insolventes», introducidos por la burguesía «en el seno de nuestros organismos para sembrar la desconfianza, el descrédito y la división». Con tales juicios de valor, los dirigentes ugetistas imponen a cualquier manifestación conflictiva de la práctica obrera, que no proceda de ellos, cierto estigma que la descalifica antes de poder someterla a un análisis político. Y, en ocasiones, el celo por salvaguardar la capacidad de iniciativa de los organismos superiores provocará la descalificación automática de organismos inferiores de la propia UGT: así, la Comisión ejecutiva nacional de la UGT de 1934 -es decir, la que ha sustituido a la presidida por Besteiro, acusada de reformista- sólo resalta de las grandes huelgas generales de la construcción y artes gráficas de Madrid el hecho de que fueran convocadas sin tener en cuenta los estatutos y que, por tanto, no eran acreedoras a la solidaridad moral ni material prevista en los estatutos y reclamada por los comités ejecutivos de las referidas industrias ${ }^{22}$.

${ }^{21}$ "Si nosotros nos conducimos de forma prudente y adecuada, la derrota de los explotadores es un hecho; si, por el contrario, nos encuentran en un terreno nervioso y díscolo... el triunfo de ellos lleva ganado un setenta por ciento. En la discusión... nada de frases fuertes, de producir escándalo, ni chabacanería; haceos dignos del lugar que ocupáis", se recomienda en "Entérate, compañero", BOA Guías-Intérpretes, Dependientes Hoteles y Similares, vii.1931, de donde es lo del sólo compañero. Lo demás puede verse en nota de la ejecutiva nacional de 21.i.1932, Memoria $y$ orden del día, página 47; y nota de la Junta Administrativa en El Sol, 12.vii.1931. La cita final es de una octavilla de la Casa del Pueblo, encabezada "Trabajadores y ciudadanos", en AHNS, número 833 .

${ }^{22}$ La referencia a los orígenes y propósitos, en "Las huelgas generales", Boletín UGT, iv.1933. La imagen de la oscuridad es muy común; puede verse, por ejemplo, "Huelgas oscuras", en BFLO Madera, ix.1930, y del mismo Boletín, "Tácticas", vi.1932, que llama a los sindicalistas "elementos acostumbrados a yivir en la obscuridad". Que sean "profesionales de la perturbación, agentes en muchos momentos de aquellos políticos logreros y reaccionarios" es de "El fracaso de la huelga sindicalista", Boletín UGT, vi. 1933. Para lo del final, véase circular "A todas las Federaciones", 8.iii.1934, en la que se "observa" que en ninguna de "las huelgas generales que se vienen produciendo en algunas industrias... se cumple lo establecido en los artículos 16 y 20 de nuestros estatutos", Boletín UGT, iii.1934. 
Es precisamente en la gestión de la huelga donde aparece con mayor nitidez el tipo de práctica sindical que mejor define a este tipo de sindicalismo. La huelga es parte de un sistema global estructurado para conquistar alguna mejora en las condiciones de trabajo y a la que sólo se debe recurrir cuando todos los otros medios se hayan agotado y en el caso exclusivo de que esté «bien organizada». En efecto, la huelga es un «arma terrible que pende como espada de Damocles» sobre la organización, «un arma arriesgada» que únicamente habrá de utilizarse «cuando esté perfectamente preparada», ya que de otra forma se puede volver contra sus autores y destruir en pocos días los esfuerzos organizativos de varios años. La buena organización y perfecta preparación se relacionan naturalmente con sus previas posibilidades de éxito: que haya fondos en la caja de resistencia; que la mayoría de los afiliados lleven al menos un año en la sociedad; que no se entablen en épocas de crisis de trabajo: son criterios de 1899 que la ejecutiva de 1932 se creyó en el deber de recordar — como hará luego la de 1934- con objeto de que se viera bien clara la diferencia de orientación y táctica con los anarcosindicalistas. En ocasiones, las condiciones son tales que resultaría prácticamente imposible convocar huelgas y cumplirlas: que todos los trabajadores del oficio estén afiliados a la sociedad; que se hayan agotado los otros medios de llegar a un acuerdo; que exista la seguridad previa de que se van a obtener las mejoras. Hasta tal punto la seguridad del resultado favorable debe influir en la convocatoria que una huelga declarada sin posibilidades de éxito carecerá del derecho a solicitar de los organismos superiores «los auxilios reglamentarios», ya que tal tipo de huelga se considera «alocado y estéril» y a ella no debían dejarse arrastrar «nuestros camaradas» ${ }^{23}$.

La buena organización de la huelga se refiere no sólo a la ocasión propicia sino a los mecanismos que es preciso poner en marcha antes y después de su declaración. Ante todo, y por expresarlo con palabras de la ejecutiva de izquierda, «reiteramos a nuestros camaradas la necesidad de supeditar toda su actuación a las instrucciones que reciban de esta ejecutiva». Este es el primer y general principio de actuación, las instrucciones que se reciban, y que recortan para el conflicto la gran autonomía de que gozan las secciones para cualquier otra actividad. Los trabajadores enfrentados en el tajo o taller a su patrono pondrán en conocimiento de los delegados sindicales los motivos de sus diferencias, relativas casi siempre a recortes de salario, prolongación de jornada, despidos arbitrarios o injustos, trastocamiento de categorías por el que se obliga del ayudante trabajo de oficial y del peón trabajo de ayudante. Los delegados intentarán una primera mediación, presumiblemente destinada al fracaso. Una vez comprobado éste, se declara con el patrono en cuestión situación de conflicto y se comunica al comité directivo de la

${ }^{23}$ La "espada de Damocles" pende naturalmente "sobre la cabeza de la organización": "Cunda el ejemplo", en El Trabajo, v.1932. La organización de la huelga, en "Criterio sobre las huelgas", Boletín UGT, v.1932. La segunda serie de condiciones es de Miguel TASENDE, "Recapacitemos", en BOSO Embaldosadores, viii.1931. Lo del final es con motivo de la negativa de la ejecutiva nacional de la UGT a practicar la "solidaridad moral" con la huelga general de la construcción madrileña de 1934, que "no debe solicitarse cuando los conflictos han pasado ya por toda clase de gestiones": "Memoria de la Comisión Ejecutiva...", en Boletín UGT, vi-vii.1934, pág. 113. 
sociedad u oficio que, a su vez, comienza rápidamente las gestiones que constituyen la parte más sobresaliente de su práctica sindical y de las que dará cuenta puntualmente en el boletín bajo el epígrafe genérico de «gestiones del comité». En el caso de que tales gestiones - por lo general: cartas, llamadas, visitas, actuaciones ante los jurados mixtos- den resultado, el conflicto se cierra sin necesidad de declarar la huelga. Se alardeará entonces de haber conseguido el objetivo «sin movilizar a ningún compañero» ${ }^{24}$.

La gestión aparece así, en un primer momento, como práctica de comité destinada a evitar, retrasar o impedir la movilización obrera. Es precisamente lo que no dejarán de denunciar los anarquistas y lo que constituye el meollo de sus ataques a la UGT. Y es así, en efecto, pero difícilmente podría ser de otra manera, dado el tipo de sindicalismo de que se trata. Son, en la mayoría de los casos, pequeñas sociedades, con recursos muy limitados que si se destinaban a socorrer a los huelguistas podían dejar endeudada a la sociedad por varios años, incluso en el caso de que se tratara de una sociedad importante. Por otra parte, el adversario es casi siempre un patrono mediano o pequeño $\mathrm{y}$, en tales casos, la movilización como primera medida es perfectamente incoherente con el limitado propósito que se persigue, que es el de hacer entrar en razón a un patrono poco razonable. Para el concreto objetivo de que un patrono pague lo que debe, proporcione las herramientas a sus obreros, respete la jornada laboral o no despida salvo en caso de fuerza mayor, debe bastar la gestión del comité de sección o de sociedad. Si se consigue lo propuesto por medio de presiones pacíficas, el comité —que comparte la opinión de que «van apareciendo medios que sustituyen con ventaja a la huelga»- presumirá a justo título de haberlo logrado sin movilizar a nadie. Para eso está ${ }^{25}$.

Para eso y para controlar y dirigir el desarrollo de la huelga si «el cerrilismo y la intransigencia» del patrono la hace inevitable. Tras probar ante la opinión pública la legitimidad de su acción echando sobre la parte contraria o, en su defecto, sobre el gobierno, la responsabilidad por la huelga, el comité comienza entonces otro tipo de gestiones: comunica con el comité de la federación de industria, si existe; impide el esquirclaje y la «traición»; se entera de lo que están dispuestos a conceder los patronos para elaborar sobre esa base las peticiones propias; solicita la práctica de la solidaridad moral y material de su industria; mantiene informados a los huelguistas; lleva el conflicto ante el organismo parita-

${ }^{24}$ La primera cita es del editorial "Serenidad y confianza" con que la nueva ejecutiva nacional saluda a los lectores de Boletín UGT, ii.1934. Para las gestiones de los comités, véase el apartado correspondiente de los boletines de las diversas sociedades. A la que se hace referencia al final es la efectuada por los dirigentes de la Federación Local de Edificación ante Agromán, por la que consiguieron que pagara a los peones de las obras del Canal 8 pesetas en lugar de 6,40 "sin movilizar a ningún compañero de los 600 que allí trabajan", La Edificación, 15.vii.1931.

${ }_{25}$ Para los graves quebrantos económicos que una huelga prolongada podía crear a las sociedades, véase El Obrero Gráfico, "Rasgos de la huelga de Madrid", ii-vi.1931, y "Problemas económicos de la Federación", iii.1932. Los subsidios de la huelga gráfica que comienza en enero de 1931 ascendieron a 316.988 pesetas, de las que 219.285 fueron préstamos que endeudaron por mucho tiempo a la Federación. Los medios que sustituyen a la huelga "y que nos permiten obtener los mismos y mayores beneficios con menos peligro individual y colectivo" es de "Cunda el ejemplo", El Trabajo, v.1932. 
rio; presiona ante las autoridades; convoca eventualmente un referéndum entre los huelguistas. De estas prácticas hay que destacar el principal protagonismo del comité sindical — sea de sociedad o de federación según la amplitud del conflictosobre los propios obreros en huelga, cuya acción tiene el sentido último de apoyar los movimientos del comité. Esto se ejemplifica tanto en el medio que se emplea para pasar la información - la pizarra de la Casa del Pueblo, a la que debe acudir el huelguista para recibir las últimas noticias sobre la marcha de su conflictocomo en el método utilizado para obtener su decisión colectiva, el referéndum, que puede durar desde primeras horas de la mañana hasta las últimas de la tarde $\mathrm{y}$, a veces, durante dos o tres días. Pizarra y referéndum - medio de comunicación y método de decisión - evitan la necesidad de asambleas que, en el mejor de los casos, se reunirán para oír el contenido del pacto firmado ya por el comité sindical y la representación patronal ${ }^{26}$.

Resalta, además de ese protagonismo del comité, la cesión de iniciativa y responsabilidad a organismos públicos y, en definitiva, al Estado, cuando el conflicto entra en vía muerta. El comité paritario es, por definición, lugar de conciliación de intereses, instrumento para alcanzar la concordia y armonía en los inevitables conflictos que surgen de la relación laboral. Al no estar garantizados tales objetivos automáticamente por la sola presencia de patronos y obreros, se espera que actúe como árbitro imparcial un representante del Estado, al que se supone situado por encima o al margen de los intereses en pugna. La práctica del conflicto ugetista/ patronal requería esta especie de coronamiento en un terreno neutral en el que las represiones patronales y la fuerza obrera se disolviesen en un arbitraje justo que posibilitara la salida del conflicto. Este papel quedaba en manos del Estado, concebido como paternal árbitro en las disputas. El esfuerzo del sindicalismo de gestión consistirá, ante todo, en ganarse el favor del Estado por medio de una cauta y prudente acción reivindicativa $\mathrm{y}$, después, en utilizarlo como instrumento de solución de conflictos ${ }^{27}$.

${ }^{26}$ La actitud general de que se habla al principio puede ilustrarse con dos ejemplos entre una multitud: con ocasión de la huelga de camareros, El Socialista, 6.xii. 1933, dirá que "la acostumbrada clientela de los bares y cafés se ha visto privada de este servicio, no por culpa de los camareros, como tendenciosamente se ha propalado en la prensa burguesa, sino a causa de la actitud de intransigencia en que se han situado los elementos patronales". Por su parte, la ejecutiva nacional quita a la Federación de campesinos cualquier responsabilidad en la huelga anunciada que si el Gobierno no evita "será porque en ello no tenga el menor interés", Circular 21 (AG/JA): "A todas las secciones pertenecientes a la Unión General de Trabajadores", AHNS, 1883.

${ }_{27}$ "La Unión General... ha procurado tener siempre representación en los organismos oficiales... no puede abandonar ni circunstancialmente las posiciones tomadas en gran número de entidades oficiales... abandonar esos sitios es abandonar la defensa de esos intereses en beneficio de los patronos y dejar el campo libre a toda clase de enemigos", dice Largo Caballero, Presente, págs. 42 y sigs. Para la "grande confiance dans l'action de l'Etat... s'il voulatit bien s'occuper de la classe ouvrière", véanse comentarios de Morizet al VIII Congreso, en Pérez Ledesma, pág. 134. La satisfacción de contar con la ayuda del Estado es también notable entre los jóvenes socialistas. Así, Carrillo reconoce que para celebrar la Escuela de Verano "nos hubiéramos tenido que servir de nuestros propios medios" en tiempos de la monarquía, y no habriamos podido "ni siquiera empezar". Ahora "el Ministerio de la Guerra nos cedió toda clase de enseres. El Patrimonio de la República, el lugar de emplazamiento. Ultimamente el Ayuntamiento nos ha subvencionado con 1.500 pesetas. En fin de cuenta, la Federación 
La huelga bien organizada no es sólo aquella que se declara con posibilidades de éxito, que se procura la legitimidad social, que resulta de la iniciativa de organismos responsables o que sigue en su desarrollo una mecánica puntualmente establecida en los estatutos, sino además aquella en la que la reclamación de mejoras se haga de tal «forma que facilite su aceptación» por los propios patronos: sólo hay que pedir lo posible cuando sea posible pedirlo. Así podría resumirse el pensamiento ugetista sobre la huelga, que tiende por supuesto a evitar su peligro, ya que, en cualquier caso, la huelga se considera como una perturbación de las relaciones armónicas y de la solución negociada que debía ser norma entre patronos y obreros. Las llamadas a la disciplina, las cautelas y prudencias, las gestiones de comité, la acción de organismos paritarios, la intervención del Estado y el recorte $\mathrm{y}$ acomodo de las demandas son otras tantas muestras del carácter de riesgo y peligro que se asigna a la huelga. Riesgo porque, si fracasa, además de vaciar la caja y endeudar a la sociedad, desmoraliza al oficio y puede provocar su desorganización y los ugetistas sabían bien de penas y sacrificios para organizar a la clase; riesgo también porque se podía provocar inútilmente el hambre de los huelguistas, ya que quien no trabaja no cobra y, viviendo al día, no cobrar es no comer. La huelga acarrea hambre y el hambre introduce todos los riesgos posibles. Por eso, las peticiones tendrían que ser aceptables: su rechazo por el patrono o por el Gobierno deberán atribuirse únicamente a su propia intransigencia ${ }^{28}$.

El ideal de concordia negociada, de huelga legítima y limitada en sus pretensiones, de Estado como árbitro, muestra bien que este sindicalismo de gestión es la perfecta horma para unas relaciones laborales de carácter todavía gremial, en las que no existe aún la distancia abstracta entre empresa y obrero, sino la muy concreta relación entre el patrono y el obrero. De ahí que las tareas que configuran la diaria actuación y los afanes de las sociedades de oficio sean todavía la vigilancia de la honestidad de sus miembros, la sanción de quienes no cumplen, la búsqueda de trabajo, el socorro en la enfermedad y la necesidad, la dignificación del oficio por medio de la obtención de mejoras y de la vigilancia para el cumplimiento de los contratos de trabajo. La UGT madrileña es así resultado histórico del tipo de estructura industrial que predomina en Madrid hasta los años veinte: importancia de las llamadas artes de la construcción, blancas, gráficas; abundancia de pequeños patronos con taller escaso de dimensiones; comercio pequeño y abundante. En sus relaciones con el patrono, al que conoce y con el que

no ha hecho otra cosa que llevar los alumnos, los profesores y su bandera roja", en Almanaque de El Socialista para 1933 (Madrid, 1932), pág. 155.

${ }_{28}$ Para todos estos criterios véase "Memoria del Comité" al II y al VI Congresos y Estatutos de 28.xi.1918 recogidos en Boletín UGT, v.1932. Sobre los perjuicios para la organización de una huelga que se piensa fracasada, pueden verse las recriminaciones de Largo Caballero a los dirigentes de la Federación de Trabajadores de la Tierra, en las actas de la reunión del Comité nacional de la UGT, 31.vii.1934, Boletín UGT, viii. 1934, págs. 211 y sigs. La vigencia de esta práctica perdura incluso en los momentos más difíciles: "El compañero Domínguez dice que tenemos que tener mucho cuidado en las peticiones que se haga a los patronos, no nos coloquen en mala situación, si éstos no pueden acceder a lo que pedimos y que será preferible que les preguntemos a ellos antes qué es lo que están dispuestos a dar para sobre esto fijar nuestro criterio, acordándose hacerlo así", "Actas Comisión Ejecutiva FLOE", sesión de 23.x.1933, celebrada en plena huelga general de la construcción, AHNS, 822, fol. 557. 
trabaja y en cuya tienda - y aun en cuya alcoba- a veces duerme, el obrero no necesita más que el arropamiento de los de su oficio o de su gremio por si trataba de extralimitarse en sus reconocidos derechos o abusar de su prepotencia. Y así, en términos de gremio contra patrono - y no todavía de clase contra clase - es como se produce la mayoría de los conflictos en que interviene el comité sindical. La Unión General de Trabajadores fue históricamente, en Madrid, la unión general de trabajadores de los pequeños o medianos patronos ${ }^{29}$.

\section{Valores morales $y$ sentimentalidad religiosa}

Así, pues, la práctica cauta y comedida de la UGT madrileña hay que relacionarla más con la condición y la propia historia de los oficios que con la idiosincrasia de los dirigentes. Es obvio que los efectos se multiplican entre sí y se sobredeterminan. La organización de los oficios y la cautelosa práctica sindical a ellos adecuada crearon un tipo de dirigente, adornado de valores coherentes con aquella organización y esta práctica que, por lo demás, reafirmará y propagará tales valores. A la necesidad de supeditar la actuación de los afiliados a las instrucciones emitidas por el comité corresponderá el énfasis en «la más estricta disciplina», que constituirá el núcleo de la respuesta de la UGT a la facilidad con que en momentos de «excitación de pasiones» - como fueron en efecto los que acompañaron y siguieron a la implantación de la República - se puede caer víctimas de «sugestiones interesadas». Por lo demás, y dado que los momentos son propicios al alocamiento, al enervamiento del espíritu de lucha, a los movimientos huelguísticos extemporáneos, a las algaradas, los dirigentes ugetistas no se cansarán de recomendar, aparte de disciplina, serenidad. $Y$ en esto, como en tantas otras cosas, nada cambia porque cambie la propia ejecutiva nacional. Es sumamente significativo que el editorial que sirve de presentación a la ejecutiva de izquierda en febreto de 1934 se titule precisamente «serenidad y disciplina». El presunto cambio radical de dirección sindical y política se expresa con idénticos términos que los utilizados por los desfenetrados reformistas cuando no se cansaban de pedir a los militantes que se mantuvieran dentro de la más «serena disciplina». En este caso, tal exhortación era sólo el exordio a que los militantes no «secundaran» iniciativas foráneas. Ahora, un lenguaje idéntico viene a cumplir la misma función: la llamada a la serenidad y la disciplina se hace para recordar a los camaradas que mantener

${ }^{29}$ Que sea "deber principal de la organización obrera" combatir "esas malas pasiones" del odio y rencor "que esclavizan el alma humana" se dice en "Máxima sindical", del BOSO Embaldosadores, ix.1930. Un "despido por actos inmorales" con el que está de acuerdo la directiva de la sociedad, en "Memoria", BOAGO Cerradores y Repartidores de Prensa, ii.1933. En ocasiones, el patrono comunica el "mal comportamiento" de si trabajador al presidente de la Agrupación y remite, además, carta de otros trabajadores que ratifican "los malos tratos y falta de respeto a la clientela": cartas del patrono y del personal de Cervecería Esparza, 25.i.1934, el presidente de la Agrupación de Camareros, en AHNS, 167. Para defensa del puesto de trabajo, véanse instrucciones cursadas en el sentido de que no se acepte a trabajar a nadie que no esté asociado: "Nuestro contrato de trabajo", en BSO Fontaneros y Vidrieros, ii.1934, y "Notas varias", en BOA Impresores, v. 1933. 
buenas relaciones con los elementos afines no quiere decir que se llegue a «confusionismos de ninguna clase». $Y$ es que, aparte de los dos valores antes mentados, el militante ugetista debía brillar por su fidelidad a la organización ${ }^{30}$.

Todo este mundo de valores que acompaña a la práctica ugetista está dominado por una profunda conciencia de los límites y embargado de cierta sentimen. talidad religiosa que calca del catolicismo sus elementos constitutivos. La conciencia de los límites la posee la UGT en grado superlativo: límites de la propia organización, que es sobre todo de oficios y, como mucho, de sociedades federadas, pero que nunca contempla al conjunto de la clase; límites de la práctica, que es prudente, con objetivos determinados, precisos, limpios y alcanzables; límites en el mundo de los valores: serenidad, disciplina, fidelidad, austeridad. $\mathrm{Y}$ respecto a la sentimentalidad laico/religiosa tan característica, podría escribirse un tratado completo. La piedra angular sobre la que se edifica esta religiosidad es la figura del Maestro -Pablo Iglesias- a quien en ocasiones se llama «santo laico» y en muchas otras «apóstol» y también, cariñosamente, «abuelo». En torno al Maestro cristalizan algunos ritos, entre los que destaca la visita «a la tumba del apóstol», y una actitud interna que se define por la fidelidad a su enseñanza, en la que se reafirma la decisión de seguir «el camino recto que nos trazó el apóstol». Tal actitud es el mejor homenaje y la más preclara muestra de que la semilla por él sembrada ha dado sus frutos de «redención». Más adelante, cuando comienza el proceso de marxistización, será Marx quien ocupe en ocasiones la misma posición que antes sólo Iglesias ocupaba. Así, la mejor «ofrenda» que se le podrá hacer será la de «continuar su obra»: «qué más podemos ofrecer al Maestro (Marx) sino continuar siendo fieles discípulos, dispuestos en todo el momento al sacrificio», y para este mismo Marx se canta, cercanas las fechas navideñas, el himno que hasta entonces y con ocasión de la misma festividad sólo los cristianos cantaban: «Hosanna, hosanna! ¡Gloria a Marx en la cumbre de su gloria ingente, y paz, dicha y ventura a los trabajadores en el llano de su existencia!» ${ }^{31}$.

${ }^{30}$ La idiosincrasia del militante socialista de principios de siglo es, según Romero Maura, factor decisivo de su fracaso en Cataluña; algunos aspectos de su carácter son aplicables al militante ugetista de los años treinta: "Era un hombre serio, honrado, austero. Sabía sus ideas superiores y se sentía a menudo por encima de los que no tenían la dicha de ser socialista... Se sabía más culto que los demás obreros y era consciente de desempeñar entre ellos un sacerdocio intelectual... sabía obedecer... desconfiaba de todo lo que podía parecer una innovación excesiva": La Rosa de Fuego. El obrerismo barcelonés de 1899 a 1909 (Barcelona, 1975), págs. 268-269. Para lo demás, "serenidad y disciplina", Boletín UGT, ii.1934.

${ }^{31}$ Los ugetistas se creen cruzados de una religión: "Fiesta mayor en el hogar societario; pero fiesta de recogimiento espiritual (...) de ofrenda plena, total, de la voluntad en el ara del sacrificio y de Ia abnegación por la Humanidad entera, haciéndonos así dignos de llamarnos cruzados de la más pura, de la más hermosa de las religiones: la religión del amor, y la paz, y la justicia universales", en BOA Arte Imprimir, xi.1931. $\mathrm{La}$ visita a la tumba y la fidelidad a los principios, entre otros, "El homenaje al Maestro", BFLO Madera, vi.1930. Lo de santo laico es de un artículo de ese título de Pascual ToMás, en El Metalúrgico, xii.1931. Seguir el camino recto es de Manuel PaRAzUELOS, "Más socialistas que nunca", en El Trabajo, xi.1933. Para lo de Marx, véase "Aniversario de Marx", BOA Estereotipadores, v.1933; y lo del hosanna es de un artículo sin desperdiico -en él se dice, por ejemplo, que "la humanidad prosigue su evolución sobre el eje de la revolución biológica y social"- de Bancario, xi-xii.1932. Este mismo discurso religioso se aplicará después a Largo Caballero, como es evidente en un libro de Carlos Baraibar. 
Tal conciencia de los límites, acompañada de esta religiosidad, se resolverán finalmente en la exaltación de una moral que debe empezar, para «un verdadero socialista», en «nuestro hogar, en la intimidad de la familia, dando ejemplo», ya que el buen ejemplo es como una «semilla que en su día puede ser productiva»; seguirá en el propio desempeño del trabajo, donde no podrán cometerse «actos inmorales» sin perder el apoyo de la organización y, por último, en la vida de la propia organización o en el desempeño de sus tareas. Así, el ugetista preferirá estudiar a chillar y, cuando se discutan las condiciones de trabajo, «nada de frases fuertes, de producir escándalo». Parece, recorriendo los boletines societarios, que no hubiera cambiado nada desde los tiempos ya lejanos en que Galdós - -según cuenta Morato- quedó convencido de que tenía ante su vista «el embrión de una sociedad mejor» cuando contemplaba «aquella actividad, aquella serenidad, aquellas secretarías llenas de hombres que dirigían y administraban colectividades, aquellas asambleas generales de tal o cual organismo en los salones, con discusiones bien ordenadas». Esta profunda identificación del ugetista con su Casa es más que un mero resultado de la afiliación a un sindicato: en la necesidad que sentían de poseer la Casa y no alquilarla, pueden oírse los ecos de un tiempo seguramente pasado en el que la serenidad del obrero era el esplendor de su sociedad ${ }^{32}$.

De ahí el no disimulado temor con que muchos acogerán la riada de gentes que, con motivo de la implantación de la República, se acercan a la Casa del Pueblo. Los dirigentes ugetistas no comprendieron lo que ese fenómeno significaba y pugnaron por mantener — sin distinción de izquierdas o derechas de la organización- idénticos criterios de actuación e idénticos principios de moral sindical y personal en unas condiciones sociales transformadas, pensando que con un cambio en la formulación de los objetivos últimos sería suficiente para recuperar el terreno cedido a otras organizaciones sindicales. En ese intento por encerrar lo que es ya práctica diferente - de movilización de masas- en los viejos principios de la práctica gremial es donde habrá que buscar la raíz que, a partir sobre todo del otoño de 1933, va a sufrir la UGT madrileña, y no en el cambio de dirección política de sus más destacados elementos. La presencia de masas obreras en las viejas organizaciones societarias planteaba nuevos problemas organizativos y prácticos. Algunos en la UGT lo vieron venir, desde principios de los treinta, de la mano de ese alud de nuevas admisiones que se les echaba encima: «debéis venir a esta Casa, que es un laboratorio permanente de la elevación cultural del obrero para su perfeccionamiento moral y su elevación económica, conscientes de vuestros

32 La referencia a la moral familiar es de BFLO Madera, vii.1931, y en esa moral es esencial evitar el alcohol que "embrutece al hombre, corrompe la familia, degrada y aniquila la especie y agota las fuentes de la población, dando seres entecos, degenerados, idiotas; da estímulos al vicio, pasto y calor a la holganza, tedio al trabajo e impulsos al suicidio", en "La taberna es un matadero del hombre", BOA Arte Imprimir, xii.1932. "No hay que chillar, compañeros; hay que estudiar", se dice en BOAGO Cerradores y Repartidores de Prensa, ii.1933. Lo de Morato es de su libro Pablo Iglesias, educador de muchedumbres (Madrid, 1931), pág. 202. El deseo de poseer la Casa llama la atención de los Moch: "Una de las características originales del obrero español es ese deseo agudo desde que está sindicado de poseer su inmueble corporativo. Il ne se contente qu'à regret de locaux loués. Tomar de las cotizaciones las sumas necesarias para comprar o construir una Casa del Pueblo es el sueño de todos los miembros de la UGT', L'Espagne republicaine (París, 1933), págs. 123-124. 
propósitos», advertía Cordero a los funcionarios recién admitidos en la organización. Y añadía: "Yo tiemblo cuando veo venir a la gente en bloque a nuestra organización», porque «su actuación no ajustada a las normas de conducta societaria puede convertir en fuerza negativa nuestra positiva valía actual» ${ }^{33}$.

La positiva valía actual se vinculada, pues, al cumplimiento de las normas de conducta societaria que, a su vez, dependían de la limitada dimensión real de la organización o, más exactamente, de su estructura gremial y de su orden jerárquico interno. Tal estructura rechazaba o temía la presencia de «gente en bloque». Toda su práctica se basaba en la acción socialmente legitimada de pequeños comités; su moral es la del trabajador austero. Esto quiere decir que la UGT era, en Madrid, más que un sindicato de masas, una unión gremio/artesanal de trabajadores de oficios. Su racionalidad interna corresponde a esa estructura industrial, que es anterior $y$, en ocasiones, yuxtapuesta, a la de grandes concentraciones de obreros con poca o ninguna cualificación. La UGT opone a cada patrono la fuerza de la organización del oficio y cuando pretende imponer su fuerza o su razón al conjunto de los patronos de un oficio o de una industria preferirá dar un rodeo por el Estado y valerse del comité paritario o del jurado mixto para canalizar las relaciones laborales en un marco corporativo. El problema para este tipo de organización surge con la misma aparición de masas de obreros en un solo lugar de producción o trabajo y dependiendo de un solo patrono que pierde ya ese nombre y asume la forma abstracta de sociedad anónima. La UGT de Madrid es una federación escasamente integrada de sociedades de oficio; su crisis será simultánea a la crisis general de los oficios. Normalmente, de esta crisis habría salido otra organización, con una estructura centralizada, con una práctica diferente y con otro tipo de dirigentes sindicales y de valores compartidos. Antes de que tal cosa pudiera ocurrir, sin embargo, otra organización, que no era de Madrid, que aquí no tenía raíces, como era el caso de la UGT, pero que pretendía conquistar Madrid, se dispuso a sacar partido de la crisis. Era la CNT. Y la CNT aprendió más rápidamente que la UGT a movilizar a esas masas de obreros sin cualificar que llegaron a la capital al calor de sus muchas obras y que ahora quedaban sin trabajo. Quizá aprendió la nueva práctica porque ella era también nueva en la capital y no tuvo que desprenderse de antiguas costumbres para atender las nuevas necesidades. Quizá también porque esas masas no produjeron a sus dirigentes ningún temblor, sino, en todo caso, cierta exaltación cósmica: su movimiento anunciaba el parto de un nuevo mundo. Y a moverlas dedicaron sus mejores esfuerzos.

33 "Acto de afirmación sinđical de los funcionarios", en El Sol, 14.viii.1931. 


\section{CUADRO 1}

Afiliados a la UGT de Madrid y su provincia en 15 de octubre de 1931, por industrias

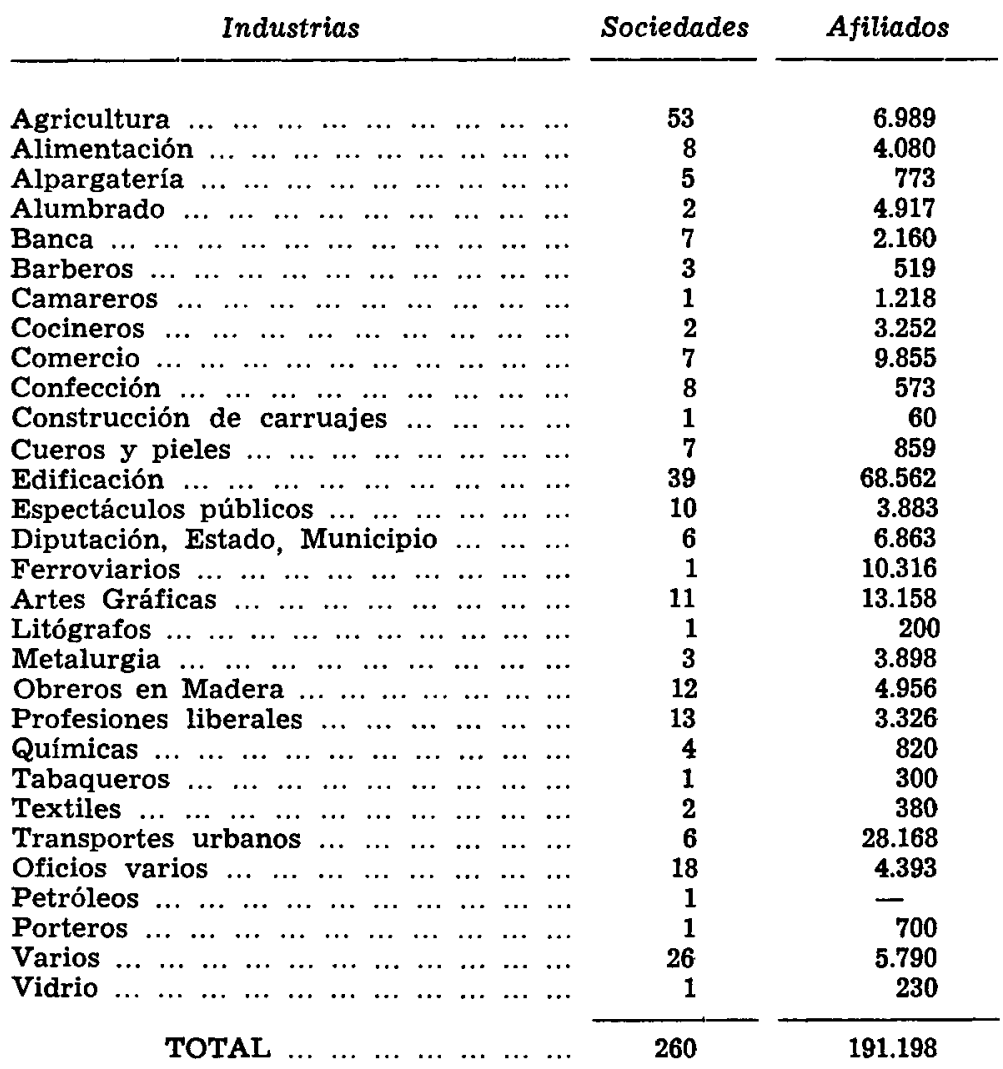

Fuente: Boletín de la Unión General de Trabajadores, 15 octubre 1931. 


\section{CUADRO 2}

Sociedades obreras de Madrid (capital y municipios limitrofes) dadas de alta en el Censo Electoral Social, con indicación de fecha de constitución y número de socios declarados en diciembre de 1931

Fecha de

constitución

Socios

Agricolas $y$ forestales:

La Aromática, Sociedad de Jardineros y Similares

Sociedad de Obreros Constructores de Objetos de Mimbre

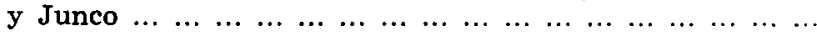

Agrupación Nacional de Técnicos de Agricultura $\ldots \ldots \ldots \ldots$

21.vi.1931

230

15.xi.1931

50

8.viii.1931

134

Alimentación:

Asociación Obreros Fabricantes de Hielo, Cerveza y Ga-

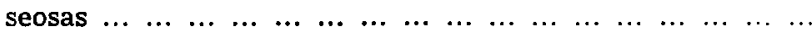

Sindicato Femenino de Obreras Fabricantes de Galletas ...

Sociedad de Dependientes de Pescaderías de Madrid y con$\begin{array}{lllllllllllllllllll} & \text { tornos } & \ldots & \ldots & \ldots & \ldots & \ldots & \ldots & \ldots & \ldots & \ldots & \ldots & \ldots & \ldots & \ldots & \ldots & \ldots & \ldots & \ldots\end{array}$

Sociedad de Dependientes de Vaquerías, Cabrerías y Despa-

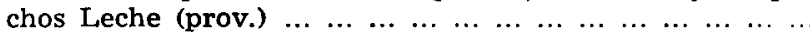

Sociedad de Mozos de Comercio, Transporte e Industria en $\begin{array}{llllllllllllllllll}\text { general } & \ldots & \ldots & \ldots & \ldots & \ldots & \ldots & \ldots & \ldots & \ldots & \ldots & \ldots & \ldots & \ldots & \ldots & \ldots & \ldots\end{array}$

Sindicato Obrero de Artes Blancas Alimenticias. Molineros.

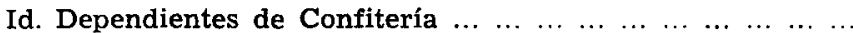

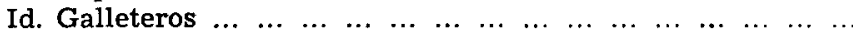

Id. Encargados, Vendedores y Mayordomos $\ldots \ldots \ldots \ldots \ldots \ldots$

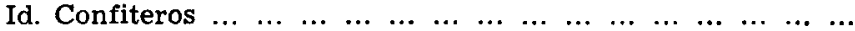

$\begin{array}{lllllllllllllllll}\text { Id. Pan Francés } & \ldots & \ldots & \ldots & \ldots & \ldots & \ldots & \ldots & \ldots & \ldots & \ldots & \ldots & \ldots & \ldots & \ldots & \ldots\end{array}$

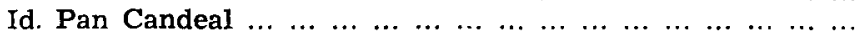

$\begin{array}{llllllllllllllll}\text { Id. Pan Viena } & \ldots & \ldots & \ldots & \ldots & \ldots & \ldots & \ldots & \ldots & \ldots & \ldots & \ldots & \ldots & \ldots & \ldots & \ldots\end{array}$

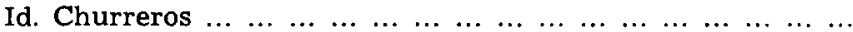

Sociedad General de Repartidores de Pan a Domicilio ... ...

Sindicatos Obreros Católicos Galleteros, Chocolateros y Si$\begin{array}{lllllllllllllllll}\text { milares } & \ldots & \ldots & \ldots & \ldots & \ldots & \ldots & \ldots & \ldots & \ldots & \ldots & \ldots & \ldots & \ldots & \ldots & \ldots & \ldots\end{array}$ 29.xii.1928

4.iii.1927

27.xi.1919

31.viii.1916

7.xi.1907

24.i. 1920

24.i. 1920

24.i.1920

24.i.1920

24.i.1920

24.i.1920

24.i.1920

24.1.1920

11.iv.1931

14.vi.1923

1.i.1919

28.ii.1932

25.ii.1929

4.i.1891

1.x.1903

3.ix.1929 24.i.1920

900

63

28

1.060

254

228

213

456

212

598

487

2.566

918

132

491

40

7.109

88

211

414

102

Material eléctrico $y$ científico:

Sociedad General de Obreros Mecánicos Dentales ... ... ...

Industrias químicas:

Sociedad Obreros/as Cerilleros "La Justicia Social", Carabanchel

$\ldots \ldots \ldots \ldots \ldots$. $\ldots \ldots \ldots \ldots$

"Fraternidad Cerillera", Sociedad Obreros Cerilleros, Cara-

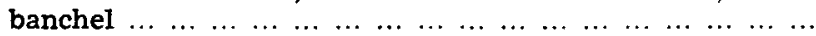

$\mathrm{N} / \mathrm{C}$

$\mathrm{N} / \mathrm{C}$ 


\section{CUADRO 2 (continuación)}

Sociedades obreras de Madrid (capital y municipios limitrofes) dadas de alta en el Censo Electoral Social, con indicación de fecha de constitución y número de socios declarados en diciembre de 1931

Fecha de constitución

Socios

Industrias químicas:

Sociedad de Obreros Curtidores y Oficios Similares ........ Sociedad Obreros en Caucho

14.x.1899

$17 . x .1918$

Federación Nacional Obreros Industrias Papel y der. Sección Madrid...

Sociedad Obreros Fabricantes Abonos, Productos Químicos y Explosivos

25.vi.1931

24.v.1931

12.v. 1905

10.v.1919

21.vi.1931

21.vi.1931

21.vi.1931

4.i.1891

Sociedad Obreros Constructores de Carruajes (Pintores) ...

Industria de la construcción:

Sociedad Obreros en Vidriería Artística $\ldots \ldots \ldots \ldots \ldots \ldots$ Portlandistas Constructores "El Cemento" $\ldots \ldots \ldots \ldots \ldots \ldots$

Sociedad Embaldosadores "La Emancipación" $\ldots \ldots \ldots \ldots \ldots$

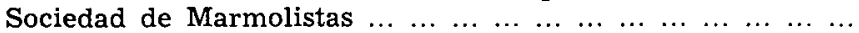

Sociedad Obreros Poceros de Madrid "La Piqueta" ... ... ...

Sociedad Obreros Biseladores de Lunas, Cortadores y Simi-

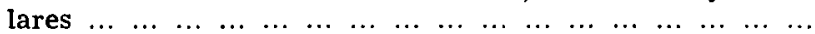

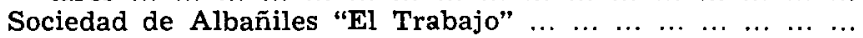

Sindicato Católico de Pintores y Similares $\ldots \ldots \ldots \ldots \ldots \ldots$

Sociedad de Oficiales Pintores-Decoradores $\ldots \ldots \ldots \ldots \ldots \ldots$

Sociedad de Operarios Fumistas $\ldots \ldots \ldots \ldots \ldots \ldots$

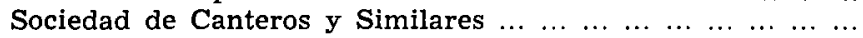

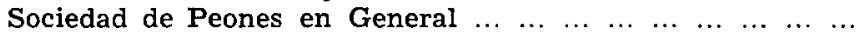

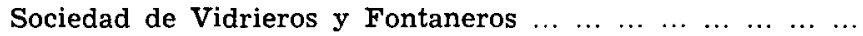

Sociedad de Carpinteros de Armar "La Verdad Social" ..

Sociedad de Obreros Esparteros y Cañistas ... ..............

Sociedad de Obreros del Ramo de la Construcción. Vallecas.

Sociedad de Obreros de Edificación y Similares. Vicálvaro.

\section{Madera:}

Sociedad de Carpinteros de Taller $\ldots \ldots \ldots \ldots \ldots \ldots$

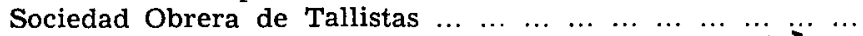

Sociedad de Aserradores Mecánicos, Afiladores, Tupistas y

$\begin{array}{llllllllllllllll}\text { Labradore } & \ldots & \ldots & \ldots & \ldots & \ldots & \ldots & \ldots & \ldots & \ldots & \ldots & \ldots & \ldots & \ldots & \ldots & \ldots\end{array}$

Sociedad General de Obreros Tapiceros $\ldots \ldots \ldots \ldots \ldots$

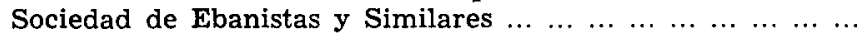

Sociedad de Obreros Tejedores de Alfombras y Tapices ... 30.xii.1927

29.iii.1920

22.xi.1897

1.v.1900

20.xi.1897

27.vii.1918

1.viii.1888

8.xi.1912

18.vi.1899

4.ix.1899

1890

5.xii.1905

21.x.1888

13.i.1893

31.v.1932

13.ii.1918

1.iii.1920

12.xi.1897

15.v. 1887

1.298

9.ix.1899

450

6.viii.1910

1.viii.1889

24.x.1931
92

265

1.000

650

327

260

10.000

20

1.592

450

650

5.115

1.288

500

$\mathrm{N} / \mathrm{C}$

535

320

\section{Textiles:}

Sociedad de Obreros Teedores de Alfombras y Tapices 


\section{CUADRO 2 (continuación)}

Sociedades obreras de Madrid (capital y municipios limitrofes) dadas de alta en el Censo Electoxal Social, con indicación de fecha de constitución y número de socios declarados en diciembre de 1931

Sociedades, por industrias

Confección, vestido y tocado:

Sociedad de Obreros Guarnicioneros y Similares ... ........ Asociación Obreros y Obreras de la Aguja y sus Similares ... Gremio Profesional Obrero Femenino de Sastras, "La In-

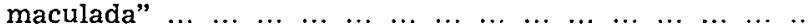

"La Unión Gorrèra", Sociedad Obreros Gorreros y Similares

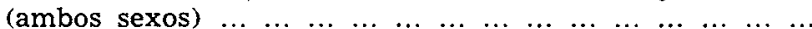

Sindicato Obrero Femenino de Modistas $\ldots \ldots$...

Sindicato Obrero Femenino de Bordadoras ... . . ........... Sindicato Obrero Femenino de Costureras en Ropa Blanca. Sociedad Obreros Tintoreros, Quitamanchas y Similares ... Sociedad Obreros en Artículos de Piel ... ... ... $\ldots . . . . . . . .$. "La Marta de España", Sociedad Obreros Peleteros ... ... ... Sociedad Operarios Sombrereros, Planchadores y Similares. "La Razón del Obrero", Asociación del Vestir (Sec. Sastres). Sociedad de Obreras Floristas y Plumistas

\section{Transporte ferroviario:}

Sindicato Nacional Ferroviario del Norte. Zona $1 .{ }^{a} \ldots \ldots \ldots$ Sindicato Nacional Ferroviario del Oeste. Zona $1 .{ }^{a} \ldots \ldots \ldots$ Sindicato Nacional Ferroviario de Madrid-Aragón . ... ... . . Sindicato Nacional Ferroviario del Metropolitano . ... ... ... Sindicato Nacional Ferroviario de la Villa del Prado . ... ... Sindicato Nacional Ferroviario de Coches-Camas ... . . . . . . . . Sindicato Nacional Ferroviario de MZA. Zona 1. ${ }^{\mathrm{a}}$
Fecha de constitución

Socios

24.ii. 1900

102

25.vi.1931

468

15.i.1929

73

21.v.1919

255

18.xii.1918

18.xii.1918

206

39

18.xii.1918

24.v.1931

27.i.1913

21.iv.1910

11.viii.1903

10.i.1923

$30 . x i .1931$

16.ii. 1929

4.xi.1925

20.v.1926

28.iii.1927

viii. 1917

1.054

6.iv.1929

202

9.xi.1925

\section{Otros transportes terrestres:}

Sociedad de Carreros del Transporte Urbano ... ... ... ......

Sociedad Obreros y Empleados Co. Tranvias Madrid y Li$\begin{array}{lllllllllllllllll}\text { mitrofes } & \ldots & \ldots & \ldots & \ldots & \ldots & \ldots & \ldots & \ldots & \ldots & \ldots & \ldots & \ldots & \ldots & \ldots & \ldots & \ldots\end{array}$

Sociedad Obreros del Transporte Mecánico de Madrid ... ...

Sociedad de Tracción de Sangre del Transporte Urbano ...

Sociedad Mozos de Comercio, Transporte e Industria en ge-

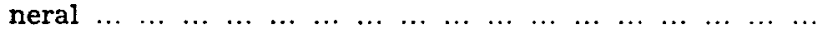

Sociedad Asistentes y Conductores Ganado Madrid y Limi-

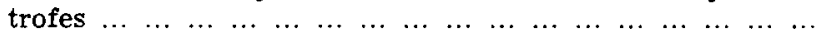

Sindicato Obreros y Empleados de la Co. Gral. de Tranvías

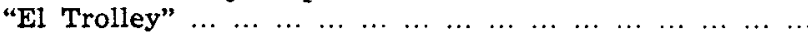

17.xii.1919

13.xii.1929

27.ix.1929

13.x.1929

7.ix.1907

1.viii.1931

8.iv.1919

Transportes maritimos $y$ aéreos:

"Icaro", Agrupación Aeronáutica Socialista

12.xi.1931 


\section{CUADRO 2 (continuación)}

Sociedades obreras de Madrid (capital y municipios limitrofes) dadas de alta en el Censo Electoral Social, con indicación de fecha de constitución y número de socios declarados en diciembre de 1931

Sociedades, por industrias
Fecha de constitución

Socios

\section{Artes Gráficas y Prensa:}

Asociación de Huecograbadores $\ldots \ldots \ldots \ldots \ldots$

8.xi.1931

$16 . x i .1910$

2.viii.1902

20.xi.1871

14.vi.1931

13.vii.1919

30.xii.1899

18.x.1907

13.x.1928

19.x.1901

27.xii.1922

23.ix.1924

17.i.1927

19.i.1927

18.iii.1903

24.vii. 1930

2.502

105

\section{Comunicaciones:}

Organización Telefónica Obrera $\ldots \ldots \ldots \ldots \ldots \ldots \ldots \ldots \ldots \ldots$ Unión de Radiotelegrafistas de España

30.vii.1931

7.xi.1926

\section{Comercio en general:}

Sindicato General de Obreros y Empleados de Comercio ...

Sociedad de Vendedores en General ......................

Sindicato General Dependientes de Comercio "La Regeneración"

19.vii.1918

Sociedad Dependientes de Pescaderías de Madrid y sus con-

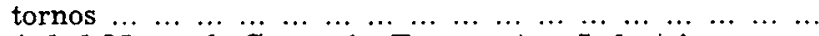

Sociedad Mozos de Comercio, Transporte e Industria ... ... ... Sociedad Dependientes de Carbonerías y Similares "La Emancipadora"

27.xi.1919

7.ix.107

7.vii. 1900

\section{Hostelería:}

Asociación General Dependientes Comercio y Empleados

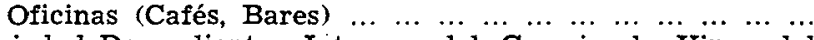
Sociedad Dependientes Internos del Gremio de Vinos del País 


\section{CUADRO 2 (continuación)}

Sociedades obreras de Madrid (capital y municipios limitrofes) dadas de alta en el Censo Electoral Social, con indicación de fecha de constitución y número de socios declarados en diciembre de 1931

Sociedades, por industrias

Fecha de
constitución Socios

Espectáculos públicos:

Asociación General Profesores de Orquesta $\ldots \ldots \ldots \ldots \ldots \ldots$

Asociación Dependientes de Teatros $\ldots \ldots \ldots \ldots \ldots \ldots$

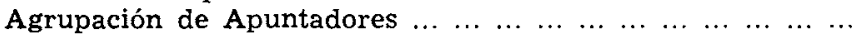

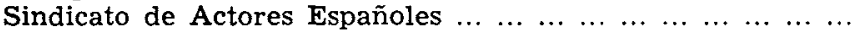

Asociación General de Actores de España $\ldots \ldots \ldots \ldots \ldots \ldots$

Asociación General de Coristas de España ... . . . . . . . . . . ...

Obreros y Empleados de Fotografía y Cinematografía ... ...

Asociación Operadores de Cinematógrafo y Similares .......

Unión Española Maestros Directores Concertadores y Pia-

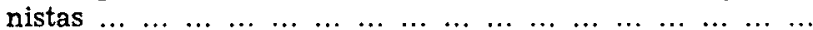

Asociación Dependientes de Espectáculos Públicos $\ldots \ldots \ldots \ldots$

10.ix.1921

1.iii.1919

11.viii.1929

7.iii. 1920

10.xi.1930

9.ix.1918

7.ii.1930

2.ix.1928

23.v. 1920

20.xi.1919

\section{6}

455

72

1.640

726

134

122

202

869

1.515

\section{Otras industrias $y$ profesiones:}

"La República", Sociedad Obreros y Empleados Hospitales y $\begin{array}{llllllllllllllll}\text { Sanatorios } & \ldots & \ldots & \ldots & \ldots & \ldots & \ldots & \ldots & \ldots & \ldots & \ldots & \ldots & \ldots & \ldots & \ldots & \ldots\end{array}$

Sindicato Médico de Madrid y su Provincia ... ... ... ....... Sindicato Obreros Municipales Vías Públicas (Limpieza) ... Sindicato General Trabajadores del Petrólec. Zona $10 \ldots \ldots$ "Vindicación", Sociedad Cigarreras, Tabaqueros, Expende-

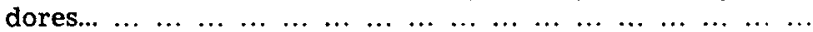

Sindicato Católico Oficios Varios, Sección Enfermeros ... ...

Sindicato Femenino de Obreras del Servicio Doméstico ... ... Asociación Practicantes de Sociedades Benéfico-Sanitarias ... Sociedad Dependientes Casinos y Similares ... . . . . . . . . . . Sociedad del Personal al Servicio de Hospitales ... ... ... ... Agrupación Profesional de Médicos de Sociedades ... ...... Agrupación de Practicantes de Cirugía de Madrid y su Pro-

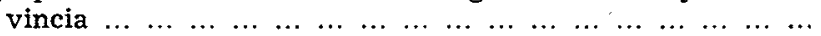

Sociedad de Porteros de Madrid y sus contornos $\ldots \ldots \ldots \ldots$

Sindicato Católico de Sirvientas y Porteros ... ... . . . . . . . Agrupación de Matronas de Madrid y sus limítrofes ... . . . . . Agrupación de Matronas de Sociedades $\ldots \ldots \ldots \ldots \ldots \ldots$

29.viii.1929

30.vi.1931

31.v.1913

8.viii. 1931

24.v.1931

18.iii.1929

2.viii.1931

1.iv. 1927

9.vi.1931

17.v.1931

5.ii.1927

18.vii.1931

20.x.1929

4.iv. 1917

12.vi.1931

25.iv.1931
34

159

47

523

439

57

148

131

254

439

429

139

753

124

84

116

Fuentes: Boletín del Ministerio de Trabajo y Previsión Social. Censo Electoral Social. Suplemento al número 29, diciembre 1932.

Boletín de la Unión General de Trabajadores de España. (Listas Provisionales del Censo Electoral Social.) Suplemento al número 34, 1931.

Boletín de la Unión General de Trabajadores de España. Suplemento al número 45, septiembre 1932. 